\title{
A 100-Year Review: Mammary development and lactation ${ }^{1}$
}

\author{
R. Michael Akers ${ }^{2}$ \\ Department of Dairy Sciences, Virginia Polytechnic Institute and State University, Blacksburg 24061
}

\begin{abstract}
What is old is new again - and with respect to the study of the mammary development and function in dairy animals, the expression resonates. Many of the mammary and milk production questions raised in the early years of the Journal of Dairy Science apply today. To be sure, scientists have filled in many details regarding, for example, identification of hormones and growth factors important in the control of mammary growth, the onset of copious milk production at calving, and maintenance of lactation. Early years focused on identification and subsequent availability of classic mammogenic, lactogenic, and galactopoietic hormones (e.g., steroids, prolactin, and growth hormone). The advent of sensitive assays to measure concentrations of these hormones and, subsequently, myriad growth factors in blood, milk, and tissues, allowed creation of multiple hypotheses to explain mammary cell proliferation and regulation of function. It is also apparent that we understand many of the fundamentals of milk removal, milking frequency, milking management, and milk ejection for successful lactation. However, some questions remain. Are the principles that were identified when cows produced markedly less milk still valid for the high-producing cows of today and the future? What mechanism(s) explain the positive effects of early increased milking frequency on subsequent milk production? Can the persistency of lactation be improved (secretory cell number vs. secretory cell function) or does early management "program" future mammary development or productivity (epigenetics, immune responsiveness, other)? The explosion of tools and techniques (Southern and Northern blots, PCR, and the "-omics" revolution) has driven an almost overwhelming evaluation of cellular and molecular functions in the mammary gland and other tissues. One key may be the discovery of a "Rosetta stone" that will allow understanding of this mass of detailed information on
\end{abstract}

\footnotetext{
Received April 4, 2017.

Accepted June 15, 2017.

${ }^{1}$ This review is part of a special issue of the Journal of Dairy Science commissioned to celebrate 100 years of publishing (1917-2017).

${ }^{2}$ Corresponding author: rma@vt.edu
}

gene expression, cell signaling, and so on. Many scientists can now better appreciate the difficulty of the dairy farmer seeking to process DHIA or Dairy Comp 305 data, milking data, weights, feeding reports, pedometer readings, or genomic evaluations to manage their operations.

Key words: lactation, mammary development, epigenetics, galactopoiesis

\section{INTRODUCTION}

Mammary development and mammary functioncould anything be more central to dairying? Indeed, without lactating animals to populate the herds of cows, goats, sheep, and other mammals, there is no dairy industry. The goal of this review is to describe what I believe are some of the mammary development research milestones that have occurred in the first 100 years of the Journal of Dairy Science (JDS). However, it is important to appreciate that my focus is on scientific advancements that have increased understanding of how the mammary gland develops and controlling factors. In addition to mammary growth, I will describe some of the key findings that increased our understanding of the onset of lactation and ongoing milk synthesis and secretion. The successful dairy, of course, depends on more than the availability of the lactating animal; other authors for this celebratory special issue will cover aspects of nutrition, health, genetics, and physiology. Finally, I have focused on highlighting papers published in JDS while understanding that many of the fundamental findings have clear parallels with scientists focused in more directly basic studies: cell biology, development biology, physiology, and, recently, the "-omics" revolution. It is also evident that dairyinterested mammary biologists and dairy scientists routinely publish in a variety of endocrine, physiology, biochemistry, reproduction, and nutrition focused scientific journals. Consequently, many important dairyrelated findings appear in those journals. Therefore, this review is not broadly comprehensive but rather seeks to highlight those contributions published in JDS. Regardless, the JDS papers that I have referenced will lead interested readers to other primary materials (listed in the timeline given in Appendix Table A1). 
What becomes clear is that many of the fundamental questions regarding mammary development and lactation have changed little over time (Petersen, 1942). As examples, consider these questions:

- What explains the shape of the typical lactation curve?

- Is persistency of milk production set?

- Does the number of secretory cells in the udder or the functional capacity of alveolar cells explain the level of milk production?

- Which is more important in explaining milk production differences - genetics or management (i.e., nature vs. nurture)?

- Are the key regulators in the "modern" high-producing dairy cow the same as described in "older" less-productive dairy cows?

- Which is more important in control of mammary growth and milk synthesis - local regulators or systemic agents?

- How does milking frequency affect mammary function and milk production?

- Why does the dry period matter and how long does it need to be?

Complete answers to these and other relevant dairy questions remain elusive and evolving. However, the continuing advancement of scientific tools, devices, and techniques provides opportunities to improve our understanding of dairy cows and other dairy animals. These efforts are critical if milk and other dairy products are to remain as key nutrients to feed the human population of the next century. I should also add that the technology sequence that took us from the transistor to the personal computer to the internet and to social media is also having major impacts on science, government, and dairying. In the absence of social media and consumerism in developed countries, would the use of effective, scientifically validated bST be an issue? Would the emphasis on animal care and animal rights, organic versus traditional production, green production methods, confusion over what constitutes milk, or the hyperbole over genetically modified foods or transgenic animals be the same?

Over many years, a variety of reviews published in JDS, often in conjunction with symposium presentations held at the annual meetings of ADSA, have served as important resources. Leading scientists in lactation biology and dairy science completed many of these reviews. Of course, many excellent reviews have been published in other journals but the focus of this contribution is on JDS. It also becomes evident upon review of the first 100 years of JDS that students and colleagues from a relatively small number of laboratories and institutions have been responsible for the majority of mammary-focused papers published in JDS. At a minimum, future students should consider these reviews to find relevant research and historical references.

\section{HOW TO MEASURE MAMMARY DEVELOPMENT? THE DEVIL IS IN THE DETAILS}

On the surface, it seems an easy matter to determine mammary growth: simply measure the mass of the udder and mass of dissected tissue components (fat pad, parenchyma, skin, and teats). Of course, sacrifice of the animals makes collection of these measurements very expensive, and time-sequence data are still limited, particularly for information related to modern, highyielding dairy cows. In addition, these simple measures do little to characterize the number or types of specific cells that compose the mammary tissue. Tissues of the developing mammary gland include the mammary parenchyma (PAR; the epithelial structures, the ducts and alveoli), stromal tissue (the connective tissue elements surrounding the developing epithelial structures, vascular and lymphatic network), the mammary fat pad (MFP), and the skin, lymph nodes, and teats. The PAR is the portion of the mammary tissue that gives rise to the mammary alveoli and associated ducts that lead to the teat or nipple in the mammary gland of the lactating cow. Because the PAR includes the lobules of alveoli that synthesize and secrete milk, this portion of the mammary tissue has received the most attention of mammary biologists. However, it is evident that the supportive stromal tissues surrounding the PAR are essential for normal development of the PAR and for maintenance of lactation in the fully formed mammary gland. Reviews describing secretory responses of mammary epithelial cells cultured on various extracellular matrix materials illustrate the importance of stromal tissue elements on cell differentiation and milk component biosynthesis and secretion (Pitelka and Hamamoto, 1977; Aggeler et al., 1988). A recent report (Stiening et al., 2008) details effects of extracellular matrix, mechanical stimulation (release of gels for cells cultured on collagen gels), and lactogenic hormones on secretory cell differentiation and gene expression in cultured bovine mammary organoids.

As outlined by Reece (1956), it was known that the amounts of secretory tissue varied in udders of cows, and the common sense conclusion was that udders of beef cows contained less secretory tissue than udders of dairy cows. Thus, the logical assumption was that higher-producing dairy cows would have udders that contain more secretory tissue than their lower-producing herdmates. But how do you quantify secretory tissue, the number of secretory cells, and supporting 
cells in the udder? Related to this, dairy physiologists began to consider how to evaluate mammary growth in calves and heifers and possible relationships between development at these early stages of development and future productivity. Several early studies (Swett, 1927, 1947; Swett and Matthews, 1934) sought relationships between udder or mammary anatomy and milk production capacity. Indeed, this fundamental question continues today (Soberon et al., 2012; Geiger et al., 2016a,b; Gelsinger et al., 2016). The reasonable conclusion is that nutrition and management both before and after weaning can influence mammary development, health, immune competency, physiology, and gene activity to modify future productivity (Kahn et al., 2011). Scientifically, the fascination comes from discovering possible mechanisms and devising useful tools and techniques to alter development and future function to make animals that are healthier and more profitable and consumers who are more satisfied.

The Mammary Gland by C. W. Turner (1952) describes and illustrates many of these early studies, many of which were conducted by Dr. Turner, his students, and collaborators at the University of Missouri. Indeed, most dairy mammary biologists in the United States between $\sim 1940$ and the 1990s can trace their academic lineage to Dr. Turner.

Many early basic studies on mammary development utilized rodents because the relatively thin, flat mammary glands of mice or rats are easy to spread onto glass slides and they can be fixed, defatted, and stained to reveal the entire developing ductal structure (Macdonald and Reece, 1960). Measurement of the number, degree of branching, and appearance of alveolar buds, for example, give a quantitative assessment of mammary development. Figure 1 illustrates examples of processed murine glands and demonstrates the readily apparent changes in prepubertal ductal development. Figure 1A shows elongating mammary ducts and the distal bulbous end buds (arrows), and Figure $1 \mathrm{~B}$ shows the development in a mouse after puberty. Thin, minimally branched ducts fill the MFP but the end buds have disappeared. Figure 1C illustrates the very compact, dense PAR development (no end buds and lack of filled fat pad) in the prepubertal ruminant. This example is a sagittal section through the entire mammary gland of a prepubertal lamb. The PAR tissue is concentrated in the area adjacent to the teat with most of the MFP being free of epithelium. Figure 1D (lower magnification) and Figure 1E show mammary ductal development in a prepubertal heifer. Many studies have evaluated the effects of stage of development, hormone ablation and replacement, and treatment with exogenous agents on mammary development. Certainly, the size and anatomy of the ruminant udder and mam- mary glands make a mouse-like evaluation impossible. It is also evident that cows and other dairy animals are not rodents. This statement is not flippant but rather serves to emphasize that substantial differences exist in the patterns of tissue development, physiological properties, and metabolism between rodents and ruminants. This concern is not new - consider the words of McCandlish (1918): "No attention will be given here to experimentation with the human subject, the goat, or mammalia other than the cow, for the simple reason that through much valuable work has been done with these subjects the results need not necessarily be directly applicable to the cow as there may be certain generic differences in physiological activity, and it is not that in some cases, e.g., with the human subject, variations in milk production can be brought about much more readily than in the case of the cow." Figure 2 provides an overview of bovine mammary development from puberty into pregnancy and into lactation.

Indeed, subtle differences exist even between dairy ruminant species (Ellis et al., 1998; Rowson et al., 2012; Capuco and Ellis, 2013). The same can be said of the many rodent-based studies aimed at better understanding breast cancer. This does not diminish the many important molecular, endocrine, and cellular findings derived from rodent models, but is a reminder that caution is necessary with uncritical extrapolation between species (Berryhill et al., 2016). Regardless, the review by Sheffield (1988) provides an interesting twist on these rodent techniques to evaluate the growth of bovine mammary tissues transplanted into the cleared (i.e., native epithelium removed) MFP of athymic nude mice. As recent examples, xenografts with bovine mammary cells are used to explore populations of mammary stem cells (Rauner and Barash, 2016) and responses of genetically engineered cells capable of secreting human milk proteins (Martignani et al., 2010).

As described by Akers (1985) and Tucker (2000), now classic studies with triply operated rodents (hypophysectomized, adrenalectomized, ovariectomized) and serial replacement of hormones (or hormone-containing tissue fractions) established the key roles of estrogen and growth hormone in mammary ductal development, progesterone and estrogen in lobulo-alveolar formation, and prolactin in lactogenesis. With the exception of the ovariectomy, the difficulties of surgery and the maintenance of animals for subsequent experimentation limited the use of extensive hormone ablation or replacement techniques in larger dairy ruminants. Regardless, numerous early studies published in JDS reported effects of various endocrine manipulations on mammary development and function. Indeed, a paper in one of the earliest issues of the journal (Hill, 1919) includes a discussion of factors responsible for 

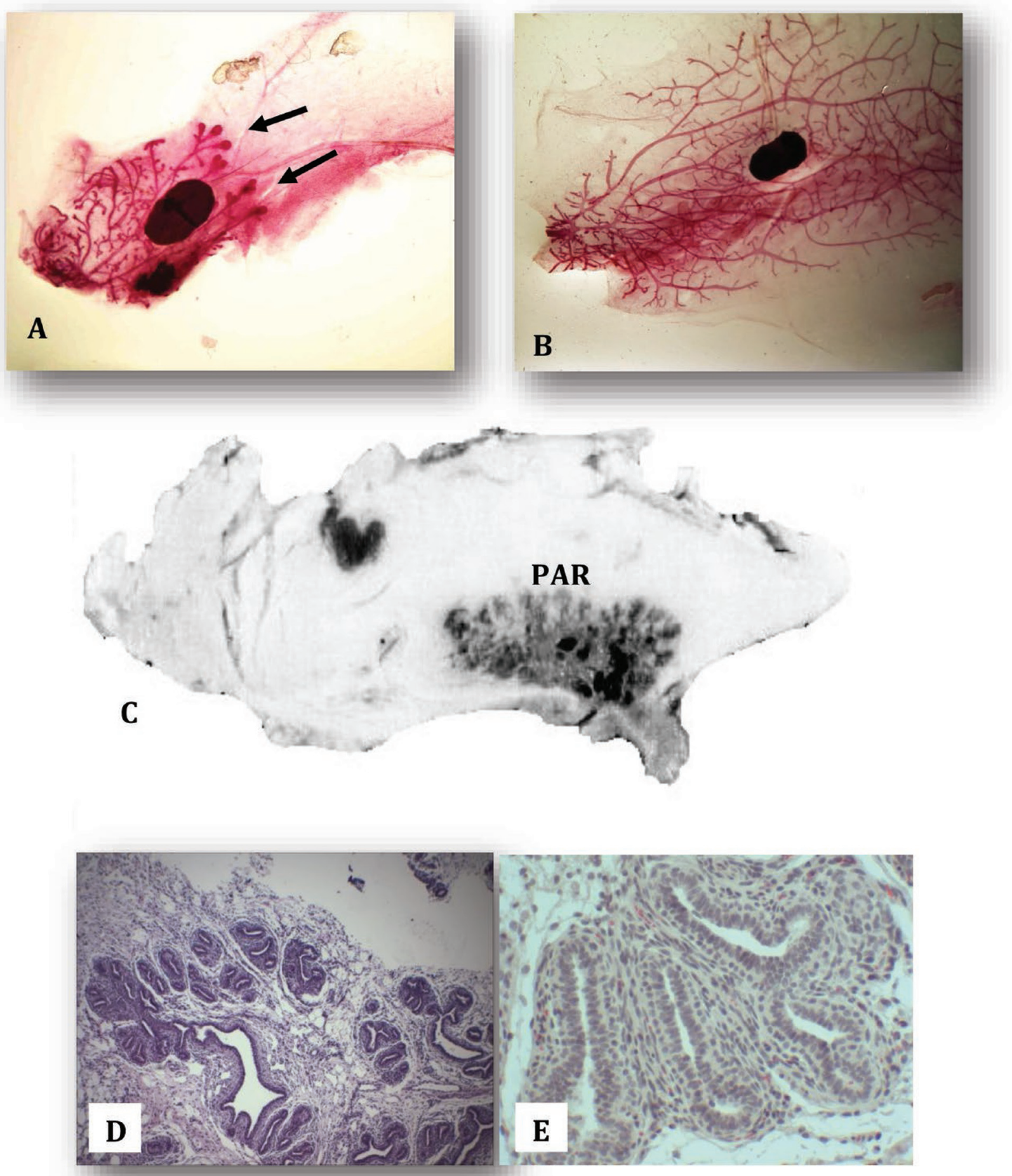

Figure 1. The appearance of mammary glands or mammary tissue at several stages of development. Panels A and B are whole mounts of mammary glands from mice. (A) Mammary growth in a prepubertal mouse at approximately 2 wk of age; the mammary ducts can be seen branching from the rudimentary tissue near teat (to the left). The arrows indicate the bulbous end buds present at the distal ends of the ducts as they progressively grow through the mammary fat pad. (B) Mammary gland of a postpubertal mouse at approximately 4 wk of age. The mammary ducts have spread throughout the mammary fat pad, and the end buds have disappeared. (C) Midsagittal section through the mammary gland of a prepubertal ewe lamb. Note the very dense development of the parenchymal tissue (PAR) in the region adjacent to the teat and gland cistern. (D) Histology of the mammary tissue from a 2-mo-old prepubertal calf. Epithelial structures are located in multiple clusters around larger ducts. (E) Cellular detail surrounding a developing epithelial cluster. Color version available online. 


\section{Overview of Bovine Mammary Growth and Development}

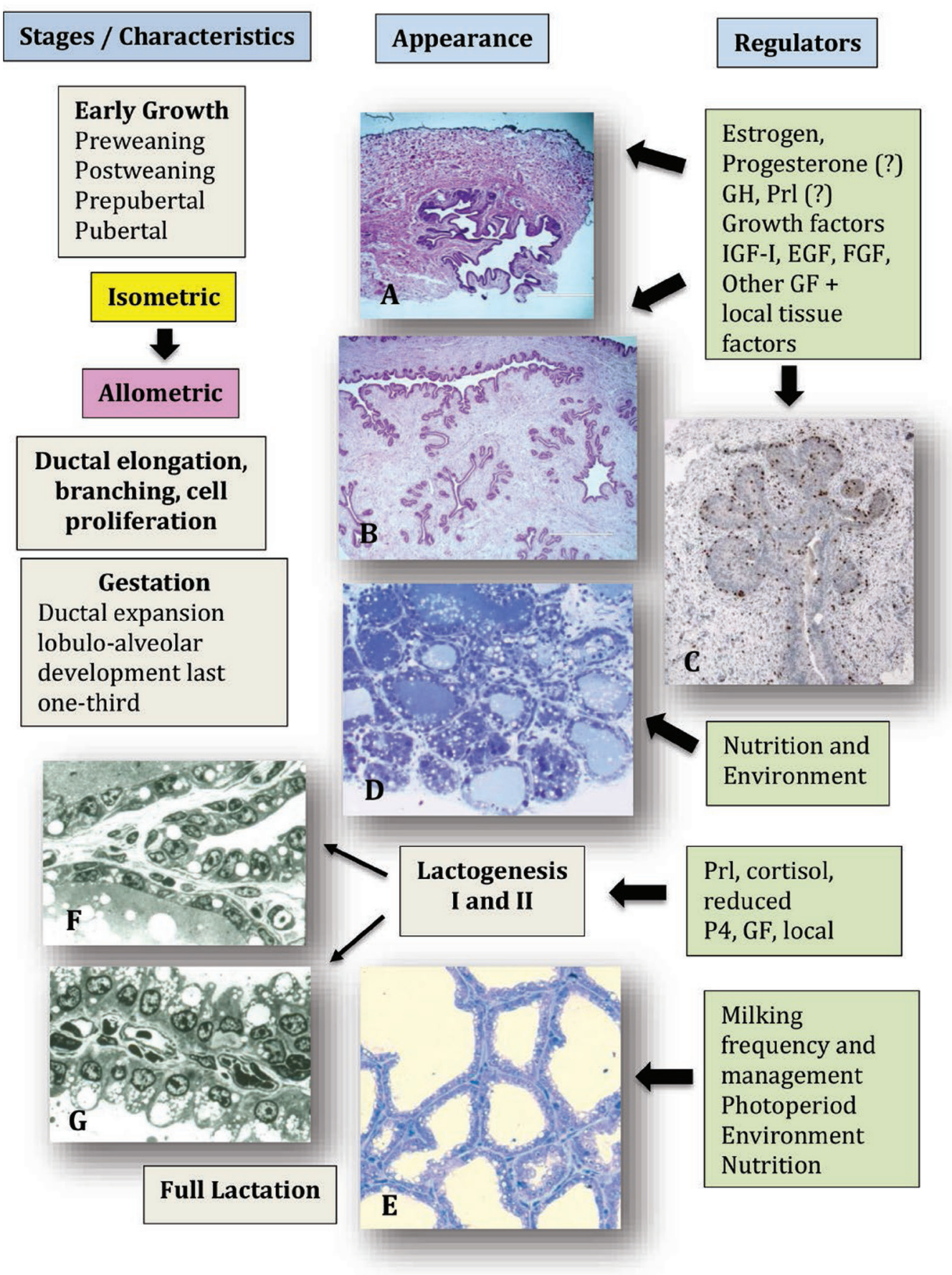

Figure 2. Overview of bovine mammary growth and development. Changes in female mammary development from the young calf to gestation and lactation are illustrated. The left column describes major development landmarks and events; the center column shows changes in histological appearance of the mammary parenchymal tissue; and the right column lists some of the regulators that are important during each of these developmental stages. (A) Rudimentary parenchyma from a very young calf. (B) Mammary parenchyma from a well-fed prepubertal calf at weaning. (C) View of a developing ductal structure from a prepubertal calf that was injected with 5-bromo-2-deoxyuridine (BrdU) 24 h before the tissue was collected. The dark spots appear in cell nuclei that have incorporated BrdU (a measure of proliferation). (D) Developing alveoli from the mammary gland of a pregnant heifer ( $\sim 170 \mathrm{~d}$ of gestation). (E) Low-power view of cross-sectioned alveoli from a cow in established lactation. The gland was thoroughly milked before tissue collection. (F) High-resolution view of alveolar tissue $\sim 2$ wk before calving; note the minimal cellular differentiation. (G) High-resolution image of alveolar tissue $\sim 2$ wk after calving; note the dramatic polarization of the cells, rounded nuclei, abundant secretory vesicles, and lipid droplets. GH = growth hormone, Prl = prolactin, EGF = epidermal growth factor, FGF $=$ fibroblast growth factor, $\mathrm{GF}=$ growth factor, $\mathrm{P} 4=$ progesterone. Color version available online. 
mammary development and milk secretion, as well as photographs of a 4-mo-old doe kid producing milk while suckling its dam. This old example emphasizes the variation in mammary development and lactation even among well-studied dairy animals. Akers (2006) described experiments demonstrating milk component biosynthesis in mammary tissue explants from bulls stimulated by addition of prolactin and effects of genetic selection for increased milk production on these responses. There are also reports of normal lactation in males of some species (Francis et al., 1994), including goats (Asdell et al., 1936; Nair et al., 1981). It remains relevant to point out that details about mammary development and lactation are available for only a small number of the mammals known to biologists. Moreover, as the examples above demonstrate, there continue to be surprises even among well-studied dairy animals.

Experimental examples of endocrine effects on mammary development include Bergman and Turner (1940), Lewis and Turner (1941, 1942), Schultze and Turner (1933), and Sykes and Wrenn (1950, 1951). Several British studies utilizing dairy goats served to extend ablation/replacement findings from rodents to dairy animals (Cowie et al., 1952, 1964, 1966). Cowie and Tindal (1961) demonstrated that milk production impaired by hypophysectomy in lactating goats could be restored with appropriate hormone replacement therapy. An extensive and comprehensive monograph (Cowie et al., 1980) provides an excellent overview of the endocrine control of mammary development and function before 1980 .

Noninvasive methods to measure mammary development are highly desirable. Some approaches include palpation, as described above, as well as use of ultrasound, X-ray, and computed tomography (CT) scanning. Sørensen et al. (1987) demonstrated that CT scanning of whole udders effectively measured the content of fat-free PAR tissue from mammary glands of prepubertal heifers. Sejrsen et al. (1986) showed that CT scanning data mirrored increases in mammary PAR in heifers treated with bST, as noted after tissue dissection. Despite the accuracy of CT scanning, the availability, expense, and lack of ability to scan intact animals has limited the use of CT to evaluate mammary development in farm animals. Esselburn et al. (2015) showed that ultrasound measurements could be used to measure changes in mammary PAR in young calves; at the time of slaughter, direct measures of PAR mass and ultrasound data were highly correlated.

As Tucker (1987) noted, "Before 1953, methods for quantifying mammary growth were either subjective or involved tedious histometric procedures." Measurement of tissue DNA evolved as a fundamental tool to mea- sure the total number of cells, with the finding that the amount of DNA per cell was essentially constant. When combined with other measures (e.g., histology) to estimate proportions of cell types and structures (e.g., stromal tissue cells, blood vessels, or leucocytes), accurate estimates of udder growth-particularly growth of the PAR - became possible. One of the first studies to use DNA content evaluated rat mammary glands (Kirkham and Turner, 1953). Williams and Turner (1961) were apparently the first to report DNA content as a measure of mammary growth in the bovine. Since then, total gland DNA with ancillary biochemical measures (protein, fat) and histology have become standards in estimating both normal and experimental mammary growth. Following a long line of studies evaluating the effects of ovarian steroids on mammary development, Sud et al. (1968) quantitatively evaluated mammary development in ovariectomized heifers to determine the amounts and ratios of estrogen and progesterone needed to produce mammary development that most closely mirrored that of pregnant heifers.

Direct measures of cell proliferation include incorporation of radiolabeled thymidine via direct counting or autoradiography (Capuco et al., 1997, 2001) or bromodeoxyuridine (Capuco et al., 2001; Berry et al., 2003; Silva et al., 2005). Alternatively, expression of transcription factors, such as Ki67, linked to cell cycle progression are frequently used to evaluate mammary cell proliferation (Capuco et al., 2001; Brown et al., 2005). The study by Capuco et al. (2002) provided an elegant combination of cell labeling with 3-dimensional reconstruction of developing ductal structures in the bovine mammary gland.

As indicated above, there has been consistent interest in early mammary development and possible relationships with future productivity. Studies have generally been concentrated in 3 areas: preweaning, weaning to puberty, and puberty to gestation. A now classic JDS paper (Sinha and Tucker, 1969) was important because it provided a quantitative assessment (DNA content) of bovine mammary parenchymal development from birth to puberty and during the estrous cycle. Perhaps more importantly, it defined differences in the rate of mammary growth relative to changes in general body growth. A key finding was that mammary growth shifted to an allometric rate of development well in advance of actual puberty. This and subsequent studies (reviewed by Tucker, 1987) indicated that mammary gland growth increased for the first few estrous cycles but returned to an isometric rate until breeding. As reviewed by Sejrsen and Purup (1997), several applied field studies in subsequent years showed that diets or feeding rates producing high rates of prepubertal gain 
were linked to lower future milk production. Related studies (Sejrsen et al., 1982, 1983) showed that a high feeding rate impaired mammary development in heifers and altered secretion of mammogenic hormones. A subsequent meta-analysis (Zanton and Heinrichs, 2005) confirmed the negative effects of high average daily gain on future milk production. Continuing studies (Meyer et al., 2006a,b) have provided further cellular and endocrine insights into this phenomenon. It seems likely that enhanced prepubertal feeding essentially truncates the period of allometric mammary growth and thus blunts overall mammary development. However, it remains unclear how relatively small differences in mammary mass (relative to growth during gestation) produce future effects on milk production or whether this is only a marker.

To add further complexity, as summarized by Kahn et al. (2011), enhanced feeding of calves before weaning correlates with increased future milk production. We (Geiger et al., 2016a,b) showed that enhanced feeding of calves increases mammary development compared with restricted feeding. Demonstration of divergent effects of feeding rate before and after weaning illustrates the malleable nature of mammary development and how little we truly understand about links between early management of calves and heifers and future performance (Capuco and Akers, 2010).

Work primarily with nursing piglets has demonstrated that early colostrum feeding has tremendous effects on subsequent development of the reproductive tract and ultimately the success of the animals. As reviewed by Bartol et al. (2013), these studies led to the lactocrine hypothesis - the concept that biologically active agents (e.g., growth factors, hormones, and bioactive peptides) in colostrum and milk act to program postnatal uterine development (Bartol et al., 2008). Given that mammary development (and that of the reproductive tract) also occurs primarily postnatally, it is not surprising that early colostrum and milk feeding likely influence future mammary development. These concepts are easier to explore in litter-bearing species (due to cost, similarity of littermates, and so on). Regardless, such studies underscore the seemingly forgotten idea that mammary secretions evolved to provide not just nutrition to the suckling young but also protection and likely signaling molecules to promote growth and development. A recent report by Wilson et al. (2017) shows that preweaning restricted-fed calves have impaired endometrial gland development and alterations in growth factor-related signaling molecules compared with enhanced-fed calves, suggesting that level of nutrition, components in milk replacer, or both, affect reproductive tract development in calves.

\section{HORMONES, GROWTH FACTORS, AND MAMMOGENESIS}

Just as rodents were important in basic studies of mammary development, responses of rodents as bioassays were important in attempts to evaluate the expression of mammogenic hormones in cattle. For example, Nibler and Turner (1929) collected urine from pregnant cows and developed extracts for injection into rats to determine the relative secretion of ovarian hormones in cows (based on changes in cells appearing in vaginal smears). Other bioassays included the pigeon crop assay (growth and histological response of tissue of the crop sac to local injections of pituitary preparations and purified fractions) to evaluate prolactin-like activity, ovarian and uterine responses in rodents to assay for estrogen or progesterone-like activity, and growth responses in rodent tibia to assay for growth hormone activity.

\section{Measuring Hormones and Growth Factors and Their Receptors}

Although JDS was never a major destination for papers relating the development of radioimmunoassays (RIA) or other immunoassays, several reports have described use and validation of assays to measure concentrations of hormones and growth factors in bovine blood, milk, saliva, and tissues. As with many techniques and tools, development of assays sensitive enough to measure circulating concentrations of these agents had their origins in basic and medical research (see Tucker, 1981). Since the 1970s, RIA or related immunoassays have evolved to measure a plethora of hormones and growth factors known to be or suspected of being involved in regulation of mammary growth and mammary function. It is difficult to overstate the explosion of information and relationships between concentrations of these agents and physiological status that arose from the use of these technologies. Two JDS reports described validation of an RIA to measure serum prolactin in cows after injection of oxytocin (Koprowski and Tucker, 1971) and to measure luteinizing hormone in the blood of heifers during an estrous cycle (Hansel and Snook, 1970). Malven and McMurtry (1974) subsequently reported procedures to measure prolactin in milk. Since that time, numerous papers have described changes in concentrations of mammary active hormones relative to puberty, the estrous cycle, gestation, and the periparturient period as well as responses to dietary treatments, stimulated mammary growth, milking, stage of lactation, and breed (Convey, 1974; Erb, 1977; Tucker, 1981, 2000). 
Related procedures using radiolabeled hormones and competitive binding to monitor changes in expression of hormone receptors in mammary tissue have been published in JDS. Examples include glucocorticoid receptors in mammary tissue slices (Gorewit and Tucker, 1976a,b), lactogenic pituitary hormones in mammary and liver cell membranes (Akers and Keys, 1984), and progesterone receptors in mammary tissue from pregnant ewes (Smith et al., 1987). As techniques evolved, Western blotting (essentially an extension of RIA and binding assays) allowed for detection and quantitation of mammary-relevant proteins separated on polyacrylamide gels and transferred to membranes. The technique used radiolabeled agents; that is, ligand binding with IGF-I to detect various IGF-I-binding proteins (Cohick, 1998; Weber et al., 2000) or antibodies to detect and measure intracellular signaling molecules (Murney et al., 2015c).

As described by Tucker (1981, 2000), the development of new tools, the isolation and identification of mammary active steroid and protein hormones, and ultimately the production and availability of these hormones and later growth factors (IGF-I and epidermal growth factor, EGF) stimulated rapid expansion of our understanding of endocrine and growth factor stimulation of mammary development. Several JDS reviews illustrate many of these relationships. Examples include circulating hormones and physiological state (Convey, 1974; Erb, 1977), mammary tissue and cell culture responses (Heald, 1974; Pitelka and Hamamoto, 1977; Houdebine et al., 1985), and actions of hormones and growth factors (Akers, 1985, 2006; Berryhill et al., 2016). Other scientists have reminded us of how little we understand or appreciate mammary and lactation variations among mammals and how insights might allow for solutions to dairy-specific issues. These examples include local versus systemic control of mammary development and function as illustrated by the wallaby and seals (Brennan et al., 2007), evolutionary and comparative aspects of lactation (Blackburn, 1993; Oftedal, 1993), and endocrine and growth factor species variation (Forsyth, 1986, 1996). Others have described new frontiers for the mammary gland (Bremel et al., 2001; Hadsell et al., 2002), including the mammary gland as bioreactor, and transgenic animals (Karatzas and Turner, 1997; Donovan et al., 2001).

\section{Somatotropin, Growth Hormone, and bST}

Interest in the effects of growth hormone $(\mathbf{G H})$ on mammary development (mammogenesis) and milk production (galactopoiesis) can hardly be overstated. A simple search using "bST", "somatotropin", or "GH" as key words in the title or abstract yielded 328 full articles in JDS as of February 2017. Certainly, a great deal of the interest in GH in the last $30 \mathrm{yr}$ or so derives from the availability of bST from recombinant DNA technology and the exhaustively studied positive effects of exogenous bST on milk production and mobilization of nutrients to support increased milk production in cows, goats, sheep, and camels. Comprehensive JDS reviews (Bauman and Currie, 1980; Peel and Bauman, 1987; Bauman, 1992) and studies (Bauman et al., 1985, 1999) illustrate my belief that bST remains the most highly tested and studied recombinant DNA-derived product ever produced for use in dairy ruminants. Given the market and consumer forces that limit use of bST in the United States and Western Europe, despite rigorous safety assurances and Food and Drug Administration approval in 1994, it remains to be seen how attitudes of companies toward development of products to increase growth or lactation responses will fare in the future. As I noted (Akers, 2006), reasons for the debate surrounding the approval and subsequent use of bST in dairy cows were varied. It is possible to stimulate native GH secretion and associated increases in milk production but this involves use of exogenous treatment with GH-releasing factor (Dahl et al., 1991, 1993). It is interesting to realize that one of the earliest large-scale demonstrations on the effectiveness of GH (pituitary fractions in this case) to increase milk production in cows was by Russian researchers Asimov and Krouze (1936) and was published in JDS. In the context of today's political atmosphere, this seems otherworldly. Indeed, current societal conditions indicate a widespread lack of confidence, belief, or reliance on science and scientific principles by the public (Nichols, 2017; Strauss, 2017; Weiss, 2017), which does not bode well for the capacity of our citizens and citizen-leaders to make logical, well-reasoned decisions. This is regardless of whether the issues are mammary development and use of recombinant proteins, genetically modified plants and animals, or occurrence and causes of climate change.

\section{Gene Expression and Signaling Cascades}

The convergence of biotechnology, gene splicing, PCR, monoclonal antibody production, and other related technologies beginning in the 1980s ushered in many new opportunities and tools to study relationships between hormones and growth factors and mammary growth and function. McCarty and McCarty (1975) were among the first researchers in JDS to discuss possible links among binding of hormones to their receptors on (or in) mammary cells, phosphorylation events, and synthesis of RNA. Gorski (1979) subsequently provided one of the first JDS reviews to discuss the significance 
of interactions between circulating concentrations of mammary active hormones, receptors, and intracellular signaling cascades relative to the mammary gland. Specific to induction of gene expression, initial studies largely depended on Northern assays. This technique required the generation of specific radiolabeled (generally ${ }^{32} \mathrm{P}$ ) nucleic acid probes that were complementary to the mRNA of interest. For this analysis, mRNA was isolated from cells or tissues, separated on gels, transferred to membranes, incubated with the probe, washed, and exposed to X-ray film to detect the mRNA of interest. This effective but laborious method allowed the study of effects of hormone stimulation, dietary treatments, and other factors on induction of gene expression. One of the earliest JDS reports described increases in casein mRNA using a dot blot assay (essentially the Northern assay without separation of RNA on a gel). Choi et al. (1988) showed that bovine mammary cells incubated with prolactin had increased expression of casein mRNAs, and greater expression of casein mRNAs was observed in mammary tissue from lactating compared with 8-mo-pregnant cows. Glimm et al. (1992) reported decreased expression of IGF-I receptor mRNA in mammary tissue of lactating cows treated with bST, and Weber et al. (2000) reported effects of feeding level and bST on expression of IGF-I and IGF-binding proteins in mammary tissue of prepubertal heifers. Schanbacher et al. (1993) and Koff and Plaut (1995) noted changes in mammary expression of lactoferrin mRNA and transforming growth factor mRNA, respectively, during the lactation cycle.

The subsequent development of quantitative realtime PCR, microarrays, and recently RNA sequencing has dramatically increased the both the frequency of gene expression measurements and the array of gene targets. A JDS keyword search for [gene expression + mammary] within the title, abstract, or keywords yielded 152 papers. A similar PubMed search restricted to [gene expression, mammary, and bovine] provided 257 hits. Examples of JDS papers related to control of mammary development include Connor et al. (2007), concerning mammary gene expression regulated by ovarian steroids, and Nørgaard et al. (2008), which tracked expression of genes involved in cell turnover in the dry period and into lactation. Broader evaluations of mammary gene expression include Piantoni et al. (2012), with a study of the effects of diet on gene expression in the PAR and MFP of calves, and changes in the clock circadian regulator gene network in mammary tissue during the transition to lactation (Wang et al., 2015). Stiening et al. (2008) provide an especially interesting and through evaluation of the impacts of lactogenic hormones and mechanical stimulation on gene expression of bovine mammary cells in culture.
Although the availability of tools for more robust and global evaluation of gene transcription has provided voluminous information and unexpected relationships between signaling and metabolic pathways and gene networks, we have learned that transcription of mRNA does not necessarily mean translation of the message and creation of the mature protein. Consequently, tools to detect and measure gene products remain an important and critical element to understand regulation of mammary development and function. Therefore, continued use of tools such as Western blotting (detection and quantitation) and functional assays, and measurement of metabolites are critical to comprehensive understanding. As examples, Murney et al. (2015a,b,c) reported effects of unilateral milking frequency on cell proliferation, gene expression for milk proteins, changes in IGF-I-linked signaling molecules and prolactin receptor, and STAT3 and STAT5 signaling pathways.

Discovery of tissue and cellular localization of signaling molecules, receptors, and other mammary relevant proteins have been an important part of learning about regulation of mammary development and function. Often, these reports have depended on various combinations of immunochemistry and immunohistochemistry. Larson and Twarog (1961) illustrated the relevance of an immunological assay when they reported quantitation of $\beta$-lactoglobulin in solution via a simple immunoprecipitation method. The earliest JDS immunocytochemistry papers involved localization of IGF-I receptors after treatment with bST (Glimm et al., 1992), effect of prolactin on induction of immunoglobulin receptors (Barrington et al., 1997), and localization of fibroblast growth factors during different development states (Plath et al., 1998). Such studies are important because they allow identification of proteins within specific populations of cells in mammary tissue or, in some cases, within cellular organelles. For example, the study by Malven and Keenan (1983) demonstrated the presence of immunoreactive prolactin within various subcellular fractions of bovine mammary cells. The study suggested that internalization of prolactin after receptor binding is linked to its transport via secretory vesicles into milk. A subsequent study (Akers and Kaplan, 1989) showed that disruption of microtubules, known to arrest cellular secretion, also interfered with transfer of prolactin from blood into milk. As suggested earlier, increased availability of specific antibodies to recognize targets on bovine cells (i.e., flow cytometry and analysis of circulating immune cells) or within bovine tissues has been key to discovery of multiple pathways and molecules that influence the bovine mammary gland. As a recent example, consider the fascinating and still unfolding story of how the classic neurotransmitter serotonin and its large family of 
receptors act to modulate milk secretion (Hernandez et al., 2008; Weaver and Hernandez, 2016).

Ellis et al. (2012) discussed the utility and promise of imaging and computer advances that increasingly allow quantitative evaluation of the expression of receptors, transcription factors, and other important mammary proteins in populations of defined mammary cells within the mammary gland. Safayi et al. (2012) report the quantitative expression of markers for myoepithelial cells in mammary tissue from heifers during early development. Velayudhan et al. (2015) and Tucker et al. (2016) have reported not just the changes in the proportion of heifer mammary epithelial cells expressing estrogen and progesterone receptors but also the difference in expression of the receptors based on quantitative multispectral imaging using immunocytochemistry. This approach is essentially quantitative Western blot analysis applied to specific, identifiable populations of cells within the developing tissue. These examples simply confirm the importance of ongoing analytical and technical advances in our continued effort to understand mammary growth and function.

\section{Cell and Tissue Culture}

Incubations of bovine mammary tissues (slices or explants) or longer-term culture of isolated mammary acini or organoids (alveolar-like or duct-like isolated epithelial structures) and isolated epithelial cells (primary or immortalized) have a long history in the study of mammary cell proliferation, differentiation, and milk component biosynthesis. Kinsella (1968) authored an early JDS study demonstrating that mammary cells isolated from lactating cows could synthesis and secrete lipids based on incorporation of radiolabeled acetate into various lipid fractions. In a similar approach, Richmond and Hood (1973) showed incorporation of radiolabeled glucose into lactose by explants of mammary tissue from a lactating cow. Heald and Saacke (1972), although using mammary tissue from lactating rats, used tissue incubations or infusion of radiolabeled leucine along with timed fixation and autoradiography of sectioned tissue to track synthesis and secretion of milk proteins. Specifically, they showed progressive peak appearance of labeled proteins in the endoplasmic reticulum (3-5 min), to the Golgi (15-20 $\mathrm{min})$, and into the alveolar lumen (40-60 min). In addition to demonstrating the utility of tissue culture, these examples illustrate the significance of availability of various radiolabeled substrates for measures of milk component biosynthesis.

Following initial characterization of isolation methods and culture procedures (Ebner et al., 1961), Larson
$(1965,1969)$ reviewed the status of regulation of milk protein biosynthesis and especially the utility of results obtained by various culture techniques. Subsequently, Larson (1972) showed the stimulatory effect of methionine on milk protein synthesis, and Rao et al. (1975) demonstrated the effects of cell density on synthesis of lactose by bovine mammary cells. Progressing from cultures with rat mammary cells, Clark et al. (1978) reported studies that defined the limiting amino acids for milk protein synthesis by bovine mammary cells in culture. Park et al. (1979) subsequently described a method to isolate acini (alveoli) from lactating bovine mammary tissue and demonstrated specific synthesis of milk proteins.

Incubations of explants (Rivera, 1972) from pregnant animals or those treated with estrogen and progesterone were especially important in the delineation of minimal hormones needed to induce the secretory cell differentiation (structural and biochemical) necessary for milk synthesis and secretion. As reviewed by Heald (1974), rodent studies first characterized the effects of addition of insulin, hydrocortisone, and prolactin on the ultrastructure of mammary alveolar cells in mammary explants. Subsequent bovine studies characterized the dramatic differentiation of mammary cells just before and after parturition, as well as biochemical and structural responses of alveolar epithelial cells to addition of lactogenic hormones (Collier et al., 1977; Nickerson et al., 1978). Additional experiments have confirmed the importance of insulin and IGF-I in maintenance of mammary tissue, the importance of glucocorticoids in differentiation of alveolar secretory cells, and the importance of prolactin in induction of milk protein and lactose biosynthesis. For example, Goodman et al. (1983) demonstrated very clearly the dramatic positive effect of prolactin on induction of $\alpha$-lactalbumin synthesis and secretion by bovine mammary explants as well as interplay between lactogenic hormones. That is, the presence of estrogen or hydrocortisone enhanced the inductive effect of prolactin, whereas progesterone had an inhibitory effect. These tissue responses closely mirrored the hormonal changes in mammogenic and lactogenic hormones around the time of parturition and correspondence with the onset of lactogenesis at calving. As noted earlier, explant cultures were also important tools in discovery of hormones and growth factors that stimulated proliferation of mammary cells.

\section{CONTROL OF LACTOGENESIS AND GALACTOPOIESIS}

As results from measurements of circulating concentrations of mammogenic and lactogenic hormones 
became widely available in the late 1960s and 1970s, increasing attention was focused on hormonal regulation of the onset of lactation and hormones involved in the maintenance of lactation. Along with accurate hormone data, tools to evaluate milk component biosynthesis (Bauman et al., 2006) helped renew focus on understanding the onset of lactation. For example, incorporation of radiolabeled precursors into specific milk components (lactose, milk proteins, lipids; Bauman et al., 1973; Mellenberger et al., 1973), enzyme assays (Baldwin, 1966, 1969; Baldwin and Cheng, 1969), direct assays for milk components, and understanding of lactose synthesis (i.e., the significance of $\alpha$-lactalbumin; Brew et al., 1968) prompted research efforts. In addition, application of higher resolution cytology and electron microscopy to characterize structural differentiation associated with onset of natural (Heald, 1974) or induced lactation (Collier et al., 1976; Croom et al., 1976) and milk removal (Akers et al., 1977; Akers and Heald, 1978) allowed researchers to piece together actions of hormones regulating differentiation of the alveolar epithelium and lactogenesis.

Just as surgical ablation and endocrine replacement helped identify key mammogenic and lactogenic hormones, selective pharmacology approaches allowed evaluations that were more specific. For example, the creation and availability of the dopamine agonist CB154 (2-Br- $\alpha$-ergocryptine) allowed selective inhibition of prolactin secretion. Treatment with CB154 reduced prolactin in cows and was associated with reduced milk production after calving. However, studies by Akers et al. $(1981 \mathrm{a}, \mathrm{b})$ showed that inhibition of prolactin secretion at calving impaired milk production in association with decreased biochemical and structural differentiation of the alveolar epithelium. Furthermore, infusion of prolactin along with treatment with CB154 restored milk production and full differentiation of the alveolar secretory cells. These data along with responses of mammary tissue and cells to prolactin confirmed the importance of prolactin for lactogenesis in cows. Interestingly, most subsequent studies (unlike in many other mammals) showed that neither inhibition nor administration of exogenous prolactin following parturition appreciably altered milk production in cows. However, recent studies using newly developed agents suggest that prolactin is likely galactopoietic in multiple dairy ruminants (Lacasse et al., 2016).

Debate surrounding regulation of lactogenesis focused on 2 hypotheses: that milk synthesis was initiated (1) because of a release from inhibition (i.e., removal of progesterone) or (2) by positive stimulation via increased secretion of cortisol and prolactin at the time of parturition. In other words, is lactogenesis pushed by positive agents or allowed to proceed by release from inhibition? The answer seems to be a bit of both. Certainly, changes in circulating concentrations of progesterone (i.e., dramatic decrease) within days and hours before parturition that coincide with increases in cortisol and prolactin just before and after parturition support this concept (Convey, 1974). Moreover, in mammary explants, prolactin-induced secretion of $\alpha$-lactalbumin, synergism with added hydrocortisone, and antagonism of secretion with added progesterone support this idea (Goodman et al., 1983). Responses involving $\alpha$-lactalbumin are especially telling, given that secretion of lactose is the primary driver of milk volume once lactation is established. In pregnant heifers, serum concentrations of $\alpha$-lactalbumin become detectable in the last trimester of gestation, with modest increases until just before calving when concentrations markedly increase. This response pattern closely mirrors a 2-stage onset of lactogenesis, with a modest increase (stage I) in milk component biosynthesis in the last month before calving followed by a marked increase (stage II) just before and after calving (McFadden et al., 1987). Measurements of mammary tissue activity (incorporation of radiolabeled precursors into milk components and increased expression of milk protein genes) and increased structural differentiation support this pattern of development. In addition to changes in circulating hormones, there are corresponding changes in the expression of glucocorticoid, prolactin, and progesterone receptors.

Specific to the role of progesterone in inhibition of onset of lactation, there is also the curious situation of simultaneous pregnancy and lactation in cows and the apparent lack of inhibition of high progesterone concentrations on milk synthesis. This seems to reflect differences in expression of progesterone receptors in mammary tissue of pregnant lactating cows compared with mammary tissue of nonlactating cows late in the dry period or in the mammary tissue of late pregnant heifers (Capuco et al., 1982). Schams et al. (2003) provided gene expression data for bovine mammary tissue expression of estrogen and progesterone receptors and an immunocytochemical survey for staining across developmental stages. However, to my knowledge, no one has evaluated either the proportion of mammary cells expressing the progesterone receptor or the degree of expression in positive cells using modern quantitative immunocytochemical techniques for tissues in these 2 distinct conditions.

As described earlier, a wealth of information demonstrates the galactopoietic responses to GH, as well as the metabolic adjustments that allow the nutrient mobilization to support increased milk production 
(Hart et al., 1979; Bauman and Currie, 1980; Bauman et al., 1985). Evidence also shows that cows selected for increased milk production correspondingly exhibit increased secretion of GH (Barnes et al., 1985; Kazmer et al., 1986).

\section{Induced Lactation}

The desire to induce lactation in nonpregnant animals, even humans, is not new. Consider the comments by Becker and McGilliard (1930): "Literature relative to milk secretion by virgin and non-fecund females, and males of several species have been reviewed extensively by Hammond (4), Hill (5), Marshall (6), Movoisin (7) and Velich (8)." Two short volumes (Fulkerson, 1979, 1981) provide summaries of work focused on the hormonal control of lactation across multiple species and, in particular, a comprehensive listing of induced lactation studies for multiple species. The first successful induction of lactation in a ruminant was in the goat (Frank and Rosenbloom, 1915) via injection of crude lipid extracts prepared from ovaries. The discovery and isolation of estrogen by Allen and Doisy (1923) led to production of synthetic estrogens and availability of these agents. Many of the early studies utilized longterm injections of estrogens and later progestins. These longer-term treatments mimicked a timeframe similar to that of gestation length (Turner et al., 1956).

Two reports (Smith and Schanbacher, 1973, 1974) ushered in renewed interest in hormonal induction of lactation that created a flurry of research activity. Their initial efforts aimed to stimulate colostrum-like secretions and immunoglobulin production in nonlactating cows. They observed that some of the steroidtreated animals began to "bag up" after a week of treatment. With continued collection of samples, the composition became less colostrum-like and more milklike in appearance. This led to the development of a short-term protocol that successfully induced lactation in most treated cows. Subsequent modifications included treatment with glucocorticoids near the time of onset of milking, treatments to increase prolactin secretion during the "lactogenic" phase of induction, effects of season, response to exogenous bST, and so on in multiple dairy ruminants. Comparisons have also included induction of animals that failed to conceive as well as heifers before normal breeding age (Macrina et al., 2011, 2014). Induced lactation in young heifers provides a means to collect milk before a normal lactation for early testing of transgenic animals as possible mammary bioreactors (Ball et al., 2000; Kaiser et al., 2017). Variations on this short-term induced lactation scheme continue to be explored.

\section{Photoperiod Effects on Mammary Development and Milk Production}

A report in Science by Peters et al. (1978), which demonstrated that supplemental lighting stimulated growth and increased milk production in dairy cows, stimulated many papers evaluating the effects of altered photoperiods on mammary growth, secretion of mammary active hormones, and feeding behavior in dairy ruminants, followed by studies to discover the mechanisms involved in these responses. Subsequent reviews (Dahl et al., 2000; Collier et al., 2006) outlined the effects of photoperiod, its practical uses, and more broadly, the environmental effects on dairy cows.

\section{Milking Interval, Milking Frequency, and Milk Ejection}

Interest in the effects of milking on milk production, composition, and productivity has a long history in JDS. Ragsdale et al. (1924) was the first JDS report concerned with the effect of milking interval; that is, the effect of milk accumulation on milk secretion. Such studies confirmed the relevance of 12-h milking intervals for twice-daily milking. A quote from a Hoard's Dairyman article emphasizes ongoing discussion of increasing milk frequency from the usual twice-daily milking: "Practical dairymen (3) have also observed the advantages of frequent milking" (Riford, L. D., 1922, It pays to milk 3 times a day. LXIII, no. 19,661). Interest in udder capacity and effects of milking interval and milk accumulation have evolved to consider effects of residual milk and internal pressure on the apparent rate of milk secretion (Tucker et al., 1961).

Milking frequency has been studied repeatedly (Pearson et al., 1979), and there is no doubt that increasing milking frequency from 2 to 3 or 4 times a day increases milk yields. However, economics and especially labor costs and availability of labor are key factors. In recent years, as herd sizes have increased, more frequent milking has also increased on many dairies. An especially interesting twist has evolved from experiments showing that increased milking or suckling in early lactation could produce carry-over effects such that the animals (or glands) that received extra milking continued to product more milk later in lactation when milking frequency returned to "normal" (Bar-Peled, 1995). This highly cited paper stimulated many studies focused on trying to understand the mechanisms responsible for the continued increase in milk production when cows revert to a normal milking frequency after a period of increased milking frequency in early lactation (Hale et al., 2003; Wall et al., 2006; Wall and McFadden, 2010; Murney et al., 2015a). 
As reviewed (Petersen, 1942; Bruckmaier and Blum, 1998), discovery of the principles behind the milk ejection reflex and factors involved in milking and suckling led to development of the modern milking machine. The first reported demonstration of the effect of oxytocin (i.e., a solution prepared from the posterior pituitary) on milk let-down was by Ott and Scott (1910). Bruckmaier and colleagues have published extensively on the effects of milking procedures on release of oxytocin (Bruckmaier and Blum, 1998), proportions of cisternal versus alveolar milk, factors influencing milk ejection, effects of milk accumulation on transport of milk and serum components across the milk-blood barrier, and general effects on milk secretion. Many of these papers have appeared in the Journal of Dairy Research (e.g., Bruckmaier and Blum, 1996; Kaskous and Bruckmaier, 2011) but recent JDS papers illustrate these ongoing efforts (Weiss et al., 2004; Waters et al., 2015; Besier et al., 2017). Indeed, Dr. Bruckmaier's extensive bibliography (i.e., 65 papers published in JDS since 2010) suggests that milk secretion research for dairy ruminants is now largely a European affair. Specific to the United States, I think this reflects a lack of ongoing institutional research support for dairy research (direct research expenses, graduate student, and technical support) and minimal competitive federal grant funds to support lactation biology research in farm animals. In addition, even among the US land-grant universities, the traditional focus on farm animal research and the balance among tripartite missions (research, teaching, and extension) are increasingly disturbed. Trends suggest that an emphasis on short-term trials to increase profitability, seeking patent possibilities, supporting local new entrepreneurs, diverting faculty efforts toward human biomedical research, "big" science, and creating teams, centers, or destination areas will continue (Fribourg, 2005). It is also evident that most basic dairy animal research funding depends on highly competitive grants. This situation seems to minimize sustained efforts in broad topical areas in favor of efforts to make the latest grant proposal awash with the latest buzzwords or scientific fads. Pundits, not so tongue in cheek, frequently comment that American agriculture, including the dairy industry, is a victim of its own success. It remains to be seen how much mammary biology research, slanted toward dairy animals, can continue in the future.

It is certainly true that concerns about support for animal agriculture research and training of future scientists are not new. Consider the following quote from Thompson (1973), "Currently there is a clarion call from numerous federal sources for relevance in research. If we gear our research primarily to someone else's need to solve immediate ... problems or moneymaking schemes, our hopes of scholarly excellence ... better faculty, better students, .. may never be filled." More recently, Senger (2008) and Roberts et al. (2009) similarly lament the relative lack of support for farm animal research and training for future animal and dairy scientists in the United States. If the internationalization of JDS over the past decade is any indication, we can be grateful that the rest of the world apparently recognizes the ongoing relevance of dairy research in general and continued study of the development and function of the mammary gland specifically.

\section{Mammary Stem Cells and the Bovine Mammary Gland}

Clearly, the past decade or so has ushered in a wealth of information regarding the identification, characterization, isolation, and quantification of putative mammary stem cells (MaSC). It should not be a surprise that progress has been much more extensive in rodent models than in cattle. Furthermore, the gold standard for identification of MaSC has been the demonstration that even a single isolated MaSC (Kordon and Smith, 1998; Shackleton et al., 2006) can regenerate a complete mammary gland when transplanted into cleared (i.e., native epithelium removed) MFP in mice. Nonetheless, some progress has been made related to identification and counting of presumptive bovine MaSC and progenitor cells. Very few MaSC-related papers appear in JDS but consideration of this topic is nonetheless very relevant.

For background, true MaSC can undergo 2 types of cell division. With symmetric division, 2 daughter stem cells are formed and the stem cell population expands. With asymmetric division, there is self-renewal of the stem cell and production of a progenitor cell. These "common" progenitor cells subsequently generate daughter cells that are the progenitors for the ductal and luminal epithelial cells and the myoepithelial cells. This scheme, as tailored to the bovine, has been previously described (Capuco et al., 2012).

Regardless of the experimental hurdles (Capuco and Ellis, 2005; Capuco et al., 2012), several studies have sought to identify stem and progenitor cells in the bovine mammary gland. Ellis and Capuco (2002) quantified proportions of lightly stained, intermediate, and darkly stained epithelial cells in growing bovine mammary glands. The population ( $\sim 10 \%$ of the total) of lightly stained epithelial cells in tissue sections accounted for about $50 \%$ of the proliferating cells. The conclusion was that these "pale" cells included a mixture of stem cells and progenitor cells. Capuco (2007) subsequently de- 
scribed the identification and quantitation of putative bovine MaSC based on long-term labeling of DNA with 5-bromo-2-deoxyuridine ( $\mathbf{B r d} \mathbf{U})$; that is, the presence of label-retaining epithelial cells (LREC) coupled with the absence of estrogen receptor (ESR1) expression. The number of heavily labeled cells correlated with expected differences in cell proliferation in regions of the developing udder based as well as proportions of MaSC based on murine studies. Choudhary et al. (2013) used laser capture microdissection and gene expression to evaluate the transcriptomes of LREC positioned in the mammary epithelium compared with LREC embedded within the epithelium. They also compared LREC with nonlabeled control cells within the ductal epithelium. They reported 592 genes differentially expressed between basal LREC and basally located control cells as well as 110 genes differentially expressed genes between LREC embedded within the epithelium and control epithelial cells also embedded within epithelium. These data support the idea that basally located ESR1negative LREC are likely true bovine MaSC, whereas LREC positioned within the epithelial layer are more likely common progenitor cells. In companion studies, these researchers (Capuco et al., 2009) showed that intramammary infusions of xanthosine increased the population of presumptive MaSC or progenitor cells.

Others have used enzymatic digestion of mammary tissue and cell sorting with panels of antibodies to separate populations of epithelial cells to characterize MaSC and progenitor cells (Motyl et al., 2011; Rauner and Barash, 2012). In particular, researchers use expression of multiple members of the cluster of differentiation (CD) proteins to segregate populations of epithelial cells believed to represent authentic MaSC and various progenitor cells. These isolated cells are then tested in various cell cultures (e.g., formation of colonies, development of mammospheres, growth response, or appearance of duct-like or alveolar-like structures) following transplantation into the cleared fat pads of immunocompromised nude mice. The appearance of specific phenotypes has allowed the putative identifications of ductal, alveolar, and myoepithelial progenitor cells and bovine MaSC (Rauner and Barash, 2016) as well as estimation of populations over the lactation cycle (Perruchot et al., 2016). Others have estimated the effects of prepubertal nutrition (Daniels et al., 2009), ovariectomy (Ellis et al., 2012), or treatment with antiestrogens (Tucker et al., 2016) on populations of putative bovine MaSC via counting of LREC. Others have estimated possible populations of bovine MaSC based on counting of cells expressing HNF4A in water buffalo (Choudhary et al., 2016) or Musashi-I in mammary tissue from sheep (Colitti and Farinacci,
2009) across different stages of development. Specific to myoepithelial cells and presumptive myoepithelial progenitor cells, Ellis and colleagues (Ballagh et al., 2008; Safayi et al., 2012; Tucker et al., 2016) have shown that smooth muscle actin or common acute lymphoblastic leukemia antigen are excellent cytoplasmic markers and transformation-related protein 63 an excellent nuclear marker for basally located myoepithelial cells and their progenitors.

Despite the experimental advances, responses of presumptive bovine MaSC or progenitors in culture or following transplantation into mice does not really reproduce the bovine mammary gland and its function. Certainly, these tools and approaches are valuable but healthy skepticism is warranted. The recent report (Bruno et al., 2017) demonstrating that the extracellular matrix isolated from the mammary gland can induce embryonic or testicular cells to acquire a mammary phenotype structurally and physiologically illustrates the significance of tissue environment in regulation of mammary morphogenesis and function. As dairy lactation physiologists, our focus is correctly on the developing glandular tissue but this finding is an important reminder that the local environment of the epithelium is also a critical player in mammary development and function.

In summary, despite many years of study evaluating the effects of hormones and growth factors, diet and management, genetics, and other factors on regulation of ruminant peripubertal mammary development and associated expression of genes and proteins, we remain far from complete understanding. However, new and exciting imaging tools (Ellis et al., 2012) and the capacity to identify and study distinct cell populations within the growing mammary gland continue to provide opportunities and unexpected approaches to decipher the keys that control mammary development and ultimately function.

\section{ACKNOWLEDGMENTS}

I acknowledge support from multiple grants with colleagues, including National Research Initiatives (NRI) USDA grants 2006-35206-15599 and 2009-35208-05778. More recently, I am grateful for grant support from USDA-National Institute of Food and Agriculture (NIFA)-Agriculture and Food Research Initiative (AFRI), 2016-67015-24575, Impact of Pre-Weaning Nutrition on Endocrine Induction of Mammary Development in Dairy Heifers awarded to R. M. Akers as well as 2016-67011-24703 (predoctoral fellowship to Adam J. Geiger) and 2017-67011-26049 (predoctoral fellowship to Ben Geiger). 


\section{REFERENCES}

Aggeler, J., C. S. Park, and M. J. Bissell. 1988. Regulation of milk protein and basement membrane gene expression: The influence of the extracellular matrix. J. Dairy Sci. 71:2830-2842.

Akers, R. M. 1985. Lactogenic hormones: Binding sites, mammary growth, secretory cell differentiation, and milk biosynthesis in ruminants. J. Dairy Sci. 68:501-519.

Akers, R. M. 2006. Major advances associated with hormone and growth factor regulation of mammary growth and lactation in dairy cows. J. Dairy Sci. 89:1222-1234.

Akers, R. M., D. E. Bauman, A. V. Capuco, G. T. Goodman, and H. A. Tucker. 1981a. Prolactin regulation of milk secretion and biochemical differentiation of mammary epithelial cells in periparturient cows. Endocrinology 109:23-30.

Akers, R. M., D. E. Bauman, G. T. Goodman, A. V. Capuco, and H. A. Tucker. 1981b. Prolactin regulation of cytological differentiation of mammary epithelial cells in periparturient cows. Endocrinology 109:31-40.

Akers, R. M., and C. W. Heald. 1978. Stimulatory effect of prepartum milk removal on secretory cell differentiation in the bovine mammary gland. J. Ultrastruct. Res. 63:316-322.

Akers, R. M., C. W. Heald, T. L. Bibb, and M. L. McGilliard. 1977. Effect of prepartum milk removal on quantitative morphology of bovine lactogenesis. J. Dairy Sci. 60:1273-1282

Akers, R. M., and R. M. Kaplan. 1989. Role of milk secretion in transport of prolactin from blood into milk. Horm. Metab. Res. $21: 362-365$.

Akers, R. M., and J. E. Keys. 1984. Characterization of lactogenic hormone binding to membranes from ovine and bovine mammary gland and liver. J. Dairy Sci. 67:2224-2235.

Allen, E., and E. A. Doisy. 1923. An ovarian hormone. Preliminary report on its localization, extraction and partial purification, and action in test animals. J. Am. Med. Assoc. 81:819-821.

Asdell, S. A., H. J. Brooks, G. W. Salisbury, and H. R. Seidenstein 1936. Experiments in the physiology of mammary development and lactation. Mem. 198. Cornell Univ. Agric. Exp. Sta., Ithaca, NY.

Asimov, G. J., and N. K. Krouze. 1936. The lactogenic preparations from the anterior pituitary and the increase in milk yield of cows. J. Dairy Sci. 20:289-306.

Baldwin, R. L. 1966. Enzymatic activities in mammary glands of several species. J. Dairy Sci. 49:1533-1542.

Baldwin, R. L. 1969. Development of milk synthesis. J. Dairy Sci. 52:731-736.

Baldwin, R. L., and W. Cheng. 1969. Metabolic changes associated with the initiation and maintenance of lactation in rats and cows. J. Dairy Sci. 52:523-528.

Ball, S., K. Polson, J. Emeny, W. Eyestone, and R. M. Akers. 2000. Induced lactation in prepubertal heifers. J. Dairy Sci. 83:2459-2463.

Ballagh, K., N. Korn, L. Riggs, S. L. Pratt, F. Dessauge, R. M. Akers, and S. Ellis. 2008. Hot topic: Prepubertal ovariectomy alters the development of myoepithelial cells in the bovine mammary gland. J. Dairy Sci. 91:2992-2995.

Bar-Peled, U., E. Maltz, I. Bruckental, Y. Folman, Y. Kali, H. Gacitua, A. R. Lehrer, C. H. Knight, B. Robinzon, H. Voet, and H. Tagari. 1995. Relationship between frequent milking or suckling in early lactation and milk production of high producing cows. J. Dairy Sci. 78:2726-2736.

Barnes, M. A., G. W. Kazmer, R. M. Akers, and R. E. Pearson. 1985 Influence of selection for milk yield on endogenous hormones and metabolites in Holstein heifers and cows. J. Anim. Sci. 60:271-284.

Barrington, G. M., T. E. Besser, C. C. Gay, W. C. Davis, J. J. Reaves, and T. B. McFadden. 1997. Effect of prolactin on in vitro expression of the bovine mammary immunoglobulin $\mathrm{G}_{1}$ receptor. J. Dairy Sci. 80:94-100.

Bartol, F. F., A. A. Wiley, and C. A. Bagnell. 2008. Epigenetic programing of porcine endometrial function and the lactocrine hypothesis. Reprod. Domest. Anim. 43(Suppl. 2):273-279.

Bartol, F. F., A. A. Wiley, D. J. Miller, A. J. Silva, K. E. Roberts M. L. Davolt, J. C. Chen, A. L. Frankshun, M. E. Camp, K. M.
Rahman, J. L. Vallet, and C. A. Bagnell. 2013. Lactation biology symposium: Lactocrine signaling and developmental programing. J. Anim. Sci. 91:696-705.

Bauman, D. E. 1992. Bovine somatotropin: Review of an emerging animal technology. J. Dairy Sci. 75:3432-3451.

Bauman, D. E., and W. B. Currie. 1980. Partitioning of nutrients during pregnancy and lactation: A review of mechanisms involving homeostasis and homeorhesis. J. Dairy Sci. 63:1514-1529.

Bauman, D. E., P. J. Eppard, M. J. DeGeeter, and G. M. Lanza 1985. Responses of high-producing dairy cows to long-term treatment with pituitary somatotropin and recombinant somatotropin. J. Dairy Sci. 68:1352-1362.

Bauman, D. E., R. W. Everett, W. H. Weiland, and R. J. Collier. 1999. Production responses to bovine somatotropin in northeast dairy herds. J. Dairy Sci. 82:2564-2573.

Bauman, D. E., D. L. Ingle, R. W. Mellenberger, and C. L. Davis 1973. Factors affecting in vitro lipogenesis by bovine mammary tissue slices. J. Dairy Sci. 56:1520-1525.

Bauman, D. E., I. H. Mather, R. J. Wall, and A. I. Lock. 2006. Major advances associated with the biosynthesis of milk. J. Dairy Sci. 89:1235-1243.

Becker, R. B., and P. C. McGilliard. 1930. Measuring the influence of hormone and mechanical stimulation by means of a non-fecund lactation. J. Dairy Sci. 13:372-379.

Bergman, A. J., and C. W. Turner. 1940. The specificity of the lactogenic hormone in the initiation of lactation. J. Dairy Sci. 23:1229 1237.

Berry, S. D. K., P. M. Jobst, S. E. Ellis, R. D. Howard, A. V. Capuco, and R. M. Akers. 2003. Mammary epithelial proliferation and estrogen receptor $\alpha$ expression in prepubertal heifers: Effects of ovariectomy and growth hormone. J. Dairy Sci. 86:2098-2105.

Berryhill, G. E., J. F. Trott, and R. C. Hovey. 2016. Mammary gland development-It's not just about estrogen. J. Dairy Sci. 99:875883.

Besier, J., G. Schüpbach-Regula, O. Wellnitz, and R. M. Bruchmaier. 2017. Effects of attachment of hind teats before cleaning and attachment of front teats on milking characteristics in automatic milking systems. J. Dairy Sci. 100:3091-3095.

Blackburn, D. G. 1993. Lactation: Historical patterns and potential for manipulation. J. Dairy Sci. 76:3195-3212.

Bremel, R. D., E. J. Homan, and T. H. Howard. 2001. Current and future promises of transgenesis for agricultural livestock in a global marketplace. J. Dairy Sci. 84(E. Suppl.):E1-E8.

Brennan, A. J., J. A. Sharp, C. Lefevre, D. Topcic, A. Auguste, M. Digby, and K. R. Nicholas. 2007. The tammar wallaby and fur seal: Models to examine local control of lactation. J. Dairy Sci. 90(E. Suppl.):E66-E75.

Brew, K., T. C. Vanaman, and R. L. Hill. 1968. The role of a-lactalbumin and the A protein in lactose synthetase: A unique mechanism for control of a biological reaction. Proc. Natl. Acad. Sci. USA 59:491-497.

Brown, E. G., M. J. VandeHaar, K. M. Daniels, J. S. Liesman, L. T. Chapin, J. W. Forest, R. M. Akers, R. E. Pearson, and M. S. Weber Nielsen. 2005. Effect of increasing energy and protein intake on mammary development in heifer calves. J. Dairy Sci. 88:595-603.

Bruckmaier, R. M., and J. W. Blum. 1996. Simultaneous recording of oxytocin release, milk ejection and milk flow during milking of dairy cows with and without prestimulation. J. Dairy Res. 63:201208.

Bruckmaier, R. M., and J. W. Blum. 1998. Oxytocin release and milk removal in ruminants. J. Dairy Sci. 81:939-949. (Review).

Bruno, R. D., J. M. Fleming, A. L. George, C. A. Boulanger, P. Schedin, and G. H. Smith. 2017. Mammary extracellular matrix directs differentiation of testicular and embryonic stem cells to form functional mammary glands in vivo. Sci. Rep. 7:40196. https://doi .org/10.1038/srep40196.

Capuco, A. V. 2007. Identification of putative bovine mammary epithelial stem cells by their retention of labeled DNA strands. Exp. Biol. Med. (Maywood) 232:1381-1390.

Capuco, A. V., and R. M. Akers. 2010. Management and environmental influences on mammary gland development and milk produc- 
tion. Chapter 9, pages 259-292 in Managing the Prenatal Environment to Enhance Livestock Productivity. P. L. Greenwood, A. W. Bell, P. E. Vercoe and G. J. Viljoen, ed. Springer Science+Business Media B. V., Dordrecht, the Netherlands.

Capuco, A. V., R. M. Akers, and J. J. Smith. 1997. Mammary growth in Holstein cows during the dry period: Quantification of nucleic acids and histology. J. Dairy Sci. 80:477-487.

Capuco, A. V., R. K. Choudary, K. M. Daniels, R. W. Li, and C. M. Evock-Clover. 2012. Bovine mammary stem cells: Cell biology meets production agriculture. Animal 6:382-393.

Capuco, A. V., and S. Ellis. 2005. Bovine mammary progenitor cells: Current concepts and future directions. J. Mammary Gland Biol. Neoplasia 10:5-15.

Capuco, A. V., S. Ellis, D. L. Wood, R. M. Akers, and W. Garrett. 2002. Postnatal mammary ductal growth: Three-dimensional imaging of cell proliferation, effects of estrogen treatment, and expression of steroid receptors in prepubertal calves. Tissue Cell $34: 143-154$.

Capuco, A. V., and S. E. Ellis. 2013. Comparative aspects of mammary gland development and homeostasis. Annu. Rev. Anim. Biosci. $1: 179-202$.

Capuco, A. V., C. M. Evock-Clover, A. Minuti, and D. L. Wood. 2009. In vivo expansion of the mammary stem / progenitor cell population by xanthosine infusion. Exp. Biol. Med. (Maywood) 234:475-482.

Capuco, A. V., P. A. Feldhoff, R. M. Akers, J. L. Wittliff, and H. A. Tucker. 1982. Progestin binding in mammary tissue of prepartum, nonlactating and postpartum, lactating cows. Steroids 40:503-517.

Capuco, A. V., D. L. Wood, R. Baldwin, K. Mcleod, and M. J. Paape. 2001. Mammary cell number, proliferation, and apoptosis during a bovine lactation: Relations to milk production and effect of bST. J. Dairy Sci. 84:2177-2187.

Choi, Y. J., W. L. Keller, I. E. Berg, C. S. Park, and A. G. Mackinlay. 1988. Casein gene expression in bovine mammary gland. J. Dairy Sci. 71:2898-2903.

Choudhary, R. K., S. Choudhary, H. Kaur, and D. Pathak. 2016. Expression of putative stem cell marker, hepatocyte nuclear factor 4 alpha, in mammary gland of water buffalo. Anim. Biotechnol. 27:182-189. https://doi.org/10.1080/10495398.2016.1164179.

Choudhary, R. K., R. W. Li, C. M. Evock-Clover, and A. V. Capuco. 2013. Comparison of the transcriptomes of long-term label retaining-cells and control cells microdissected from mammary epithelium: An initial study to characterize potential stem/progenitor cells. Front. Oncol. 3:21.

Clark, R. M., P. T. Chandler, and C. S. Park. 1978. Limiting amino acids for milk protein synthesis by bovine mammary cells in culture. J. Dairy Sci. 61:408-413.

Cohick, W. S. 1998. Role of the insulin-like growth factors and their binding proteins in lactation. J. Dairy Sci. 81:1769-1777.

Colitti, M., and M. Farinacci. 2009. Expression of a putative stem cell marker, Musashi 1, in mammary glands of ewes. J. Mol. Histol. 40:139-149.

Collier, R. J., D. E. Bauman, and R. L. Hays. 1977. Lactogenesis in explant cultures of mammary tissue from pregnant cows. Endocrinology 100:1192-1200.

Collier, R. J., W. J. Croom, D. E. Bauman, R. L. Hays, and D. R. Nelson. 1976. Cellular studies of mammary tissue from cows hormonally induced into lactation: Lactose and fatty acid synthesis. J. Dairy Sci. 59:1226-1231.

Collier, R. J., G. E. Dahl, and M. J. VanBaale. 2006. Major advances associated with environmental effects on dairy cattle. J. Dairy Sci. $89: 1244-1253$.

Connor, E. E., M. J. Meyer, R. W. Li, M. E. Van Amburgh, Y. R. Boisclair, and A. V. Capuco. 2007. Regulation of gene expression in the bovine mammary gland by ovarian steroids. J. Dairy Sci. 90(E. Suppl.):E55-E65.

Convey, E. M. 1974. Serum hormone concentrations in ruminants during mammary growth, lactogenesis, and lactation: A review. J. Dairy Sci. 57:905-917.
Cowie, A. T., S. J. Folley, F. H. Malpress, and K. C. Richardson. 1952. Studies on the hormonal induction of mammary growth and lactation in the goat. J. Endocrinol. 8:64-88.

Cowie, A. T., I. A. Forsyth, and I. C. Hart. 1980. Hormonal Control of Lactation. Monographs on Endocrinology, Vol 15, Springer-Verlag, Berlin. Germany.

Cowie, A. T., G. S. Knaggs, J. S. Tindal, and A. Turvey. 1964. Complete restoration of lactation in the goat after hypophysectomy. J. Endocrinol. 28:267-279.

Cowie, A. T., and J. S. Tindal. 1961. The maintenance of lactation in the goat after hypophysectomy. J. Endocrinol. 23:79-96.

Cowie, A. T., J. S. Tindal, and A. Yokoyama. 1966. The induction of mammary growth in the hypophysectomized goat. J. Endocrinol. $34: 185-195$.

Croom, W. J., R. J. Collier, D. E. Bauman, and R. L. Hays. 1976. Cellular studies of mammary tissue from cows hormonally induced in to lactation: Histology and ultrastructure. J. Dairy Sci. 59:1232-1246.

Dahl, G. E., B. A. Buchanan, and H. A. Tucker. 2000. Photoperiodic effects on dairy cattle: A review. J. Dairy Sci. 83:885-893.

Dahl, G. E., L. T. Chapin, M. S. Allen, W. M. Moseley, and H. A. Tucker. 1991. Comparison of somatotropin and growth hormonereleasing factor on milk yield, serum hormones, and energy status. J. Dairy Sci. 74:3421-3428.

Dahl, G. E., L. T. Chapin, W. M. Moseley, and H. A. Tucker. 1993. Galactopoietic effects of recombinant somatotropin and growth hormone-releasing factor in dairy cows. J. Dairy Sci. 76:1550-1557.

Daniels, K. M., A. V. Capuco, M. L. McGilliard, R. E. James, and R. M. Akers. 2009. Effects of milk replacer formulation on measures of mammary growth and composition in Holstein heifers. J. Dairy Sci. 92:5937-5950.

Donovan, S. M., M. H. Monaco, G. T. Bleck, J. B. Cook, M. s. Noble, W. L. Hurley, and M. B. Wheeler. 2001. Transgenic over-expression of bovine $\alpha$-lactalbumin and human insulin-like growth factor-I in porcine mammary gland. J. Dairy Sci. 84(E. Suppl.):E216-222.

Ebner, K. E., C. R. Hoover, E. C. Hagerman, and B. L. Larson. 1961. Cultivation and properties of bovine mammary cell cultures. Exp. Cell Res. 23:373-385.

Ellis, S., R. M. Akers, A. V. Capuco, and S. Safayi. 2012. Bovine mammary epithelial cell lineages and parenchymal development. J. Anim. Sci. 90:1666-1673.

Ellis, S., and A. V. Capuco. 2002. Cell proliferation in bovine mammary epithelium: Identification of the primary proliferative cell population. Tissue Cell 34:155-163.

Ellis, S., T. B. McFadden, and R. M. Akers. 1998. Prepubertal ovine mammary development is unaffected by ovariectomy. Domest. Anim. Endocrinol. 15:217-225.

Erb, R. E. 1977. Hormonal control of mammogenesis and onset of lactation in cows-A review. J. Dairy Sci. 60:155-169.

Esselburn, K. M., T. M. Hill, H. G. Bateman II, F. L. Fluharty, S. J. Moeller, K. M. O'Diam, and K. M. Daniels. 2015. Examination of weekly parenchymal area by ultrasound, mammary mass, and composition in Holstein heifers reared on 1 or 3 diets from birth to 2 months of age. J. Dairy Sci. 98:5280-5293.

Forsyth, I. A. 1986. Variation among species in the endocrine control of mammary growth and function: The roles of prolactin, growth hormone, and placental lactogen. J. Dairy Sci. 69:886-903.

Forsyth, I. A. 1996. The insulin-like growth factor and epidermal growth factor families in mammary growth in ruminants: Action and interaction with hormones. J. Dairy Sci. 79:1085-1096.

Francis, C. M., E. L. P. Anthony, J. A. Burton, and T. H. Kunz. 1994 Lactation in male fruit bats. Nature 367:691-692.

Frank, R. T., and I. Rosenbloom. 1915. I. Physiologically active substance contained in the placenta and in the corpus luteum. Surg. Gynecol. Obstet. 21:646-649.

Fribourg, H. 2005. Where are land-grant colleges headed? J. Nat. Resour. Life Sci. Educ. 34:40-43.

Fulkerson, W. J. 1979. Hormonal control of lactation. Vol. 1. Annual Research Reviews. Eden Press Inc., Quebec, Canada.

Fulkerson, W. J. 1981. Hormonal control of lactation. Vol. 2. Annual Research Reviews. Eden Press Inc., Quebec, Canada. 
Geiger, A. J., C. L. M. Parsons, and R. M. Akers. 2016b. Feeding a higher plane of nutrition and providing exogenous estrogen increases mammary gland development in Holstein heifer calves. J. Dairy Sci. 99:7642-7653.

Geiger, A. J., C. L. M. Parsons, R. E. James, and R. M. Akers. 2016a. Growth, intake, and health of Holstein heifer calves fed an enhanced preweaning diet with or without postweaning estrogen. J. Dairy Sci. 99:3995-4004.

Gelsinger, S. L., A. J. Heinrichs, and C. M. Jones. 2016. A metaanalysis of the effects of preweaned calf nutrition and growth on first-lactation performance. J. Dairy Sci. 99:6206-6214.

Glimm, D. R., V. E. Baracos, and J. J. Kennelly. 1992. Northern and in situ hybridization analyses of the effects of somatotropin on bovine mammary gene expression. J. Dairy Sci. 75:2687-2705.

Goodman, G. T., R. M. Akers, K. H. Friderici, and H. A. Tucker. 1983 Hormonal regulation of alpha-lactalbumin secretion from bovine mammary tissue cultured in vitro. Endocrinology 112:1324-1330.

Gorewit, R. C., and H. A. Tucker. 1976a. Corticoid binding in mammary tissue slices from lactating cows. J. Dairy Sci. 59:232-240.

Gorewit, R. C., and H. A. Tucker. 1976b. Glucocorticoid binding in mammary tissue slices of cattle in various physiological states. J. Dairy Sci. 59:1890-1896.

Gorski, J. 1979. Endocrine factors in genetic improvement of milk production. J. Dairy Sci. 62:814-817.

Hadsell, D. L., S. G. Bonnette, and A. V. Lee. 2002. Genetic manipulation of the IGF-I axis to regulate mammary gland development and function. J. Dairy Sci. 85:365-377.

Hale, S. A., A. V. Capuco, and R. A. Erdman. 2003. Milk yield and mammary growth effects due to increased milking frequency during early lactation. J. Dairy Sci. 86:2061-2071.

Hansel, W., and R. B. Snook. 1970. Pituitary ovarian relationships in the cow. J. Dairy Sci. 53:945-961.

Hart, I. C., J. A. Bines, and S. V. Morant. 1979. Endocrine control of energy metabolism in the cow: Correlations of hormones and metabolites in high and low yielding cows for stages of lactation. J. Dairy Sci. 62:270-277.

Heald, C. W. 1974. Hormonal effects on mammary cytology. J. Dairy Sci. 57:917-925.

Heald, C. W., and R. G. Saacke. 1972. Cytological comparison of milk protein synthesis of rat mammary tissue in vivo and in vitro. J. Dairy Sci. 55:621-628.

Hernandez, L. L., C. M. Stiening, J. B. Wheellock, L. H. Baumgard, A. M. Parkhurst, and R. J. Collier. 2008. Evaluation of serotonin as a feedback inhibitor of lactation in the bovine. J. Dairy Sci. 91:1834-1844.

Hill, R. L. 1919. An exceptional case of milk secretion and its bearing on the theories concerning mammary development. J. Dairy Sci. $2: 19-27$.

Houdebine, L. M., J. Djiane, I. Dusandter-Fourt, P. Martel, P. A. Kelly, E. Devinoy, and J. Servely. 1985. Hormonal action controlling mammary activity. J. Dairy Sci. 68:489-500.

Kahn, M. A., D. M. Weary, and M. A. G. von Keyserlingk. 2011. Invited review: Effects of milk ration on solid feed intake, weaning, and performance in dairy heifers. J. Dairy Sci. 94:1071-1081.

Kaiser, G. G., N. C. Mucci, V. González, L. Sánchez, J. A. Parrón, M. D. Pérez, M. Calvo, J. F. Aller, F. A. Hozbor, and A. A. Mutto. 2017. Detection of human lactoferrin and lysozyme produced in a bitransgenic cow. J. Dairy Sci. 100:1605-1617.

Karatzas, C. N., and J. D. Turner. 1997. Toward altering milk composition by genetic manipulation: Current status and challenges. J. Dairy Sci. 80:2225-2232.

Kaskous, S., and R. M. Bruckmaier. 2011. Best combination of prestimulation and latency period duration before cluster attachment for efficient oxytocin release and milk ejection in cows with low to high udder-filling levels. J. Dairy Res. 78:97-104.

Kazmer, G. W., M. A. Barnes, R. M. Akers, and R. E. Pearson. 1986. Effect of genetic selection for milk yield and increased milking frequency on plasma growth hormone and prolactin concentrations in Holstein cows. J. Anim. Sci. 63:1220-1227.

Kinsella, J. E. 1968. Lipid biosynthesis by bovine mammary cells in vitro. J. Dairy Sci. 51:1968-1970.
Kirkham, W. R., and C. W. Turner. 1953. Nucleic acids of the mammary gland of rats. Proc. Soc. Exp. Biol. Med. 83:123-126.

Koff, M. D., and K. Plaut. 1995. Expression of transforming growth factor- $\alpha$-like messenger ribonucleic acid transcripts in the bovine mammary gland. J. Dairy Sci. 78:1903-1908.

Koprowski, J. A., and H. A. Tucker. 1971. Failure of oxytocin to initiate prolactin or luteinizing hormone release in lactating dairy cows. J. Dairy Sci. 54:1675-1680.

Kordon, E. C., and G. H. Smith. 1998. An entire functional mammary gland may comprise the progeny from a single cell. Development 125:1921-1930

Lacasse, P., S. Ollier, V. Lollivier, and M. Boutinaud. 2016. New insights into the importance of prolactin in dairy ruminants. J. Dairy Sci. 99:864-874.

Larson, B. L. 1965. Biosynthesis of milk proteins. J. Dairy Sci. 48:133139.

Larson, B. L. 1969. Biosynthesis of milk. J. Dairy Sci. 52:737-747.

Larson, B. L. 1972. Methionine stimulation of milk protein synthesis in bovine mammary cell cultures. J. Dairy Sci. 55:629-631.

Larson, B. L., and J. M. Twarog. 1961. Determination of $\beta$-lactoglobulin in complex systems by a simple immunological procedure. J. Dairy Sci. 44:1843-1856.

Lewis, A. A., and C. W. Turner. 1941. Effect of stilbestrol on the mammary gland of the mouse, rat, rabbit, and goat. J. Dairy Sci $24: 845-860$

Macdonald, G., and R. P. Reece. 1960. Area measurement of rat mammary glands. J. Dairy Sci. 43:1658.

Macrina, A. L., A. C. W. Kauf, D. A. Pape-Zambito, and R. S. Kensinger. 2014. Induced lactation in heifers: Effects of dexamethasone and age at induction on milk yield and composition. J. Dairy Sci 97:1446-1453

Macrina, A. L., P. R. Tozer, and R. S. Kensinger. 2011. Induced lactation in pubertal heifers: Efficacy, response to bovine somatotropin and profitability. J. Dairy Sci. 94:1355-1364.

Malven, P. V., and T. W. Keenan. 1983. Immunoreactive prolactin in subcellular fractions from bovine mammary tissue. J. Dairy Sci $66: 1237-1242$

Malven, P. V., and J. P. McMurtry. 1974. Measurement of prolactin in milk by radioimmunoassay. J. Dairy Sci. 57:411-415.

Martignani, E., Pl. Eirew, P. Accomero, C. J. Eaves, and M. Baratta. 2010. Human milk protein production in xenografts of genetically engineered bovine mammary epithelial stem cells. PLoS One 5:e13372. https://doi.org/10.1371/journal.pone.0013372.

McCandlish, A. C. 1918. The possibility of increasing milk and butterfat production by the administration of drugs. J. Dairy Sci. $1: 475-486$

McCarty, K. S., and K. S. McCarty Jr.. 1975. Early mammary gland responses to hormones. J. Dairy Sci. 58:1022-1032.

McFadden, T. B., R. M. Akers, and G. W. Kazmer. 1987. Alpha-lactalbumin in bovine serum: Relationships with udder development and function. J. Dairy Sci. 70:259-264.

Mellenberger, R. W., D. E. Bauman, and D. R. Nelson. 1973. Metabolic adaptations during lactogenesis: fatty acid and lactose synthesis in cow mammary tissue. Biochem. J. 136:741-748.

Meyer, M. J., A. V. Capuco, D. A. Ross, L. M. Lintault, and M. E. Van Amburgh. 2006a. Developmental and nutritional regulation of the prepubertal heifer mammary gland: I. Parenchyma and fat pad mass and composition. J. Dairy Sci. 89:4289-4297.

Meyer, M. J., A. V. Capuco, D. A. Ross, L. M. Lintault, and M. E. Van Amburgh. 2006b. Developmental and nutritional regulation of the prepubertal heifer mammary gland: II. Epithelial cell proliferation, parenchymal accretion rate, and allometric growth. J. Dairy Sci. 89:4298-4304.

Motyl, T., J. B. Bierla, M. Kozlowski, M. Gajewska, B. Gajkowska, and M. Koronkiewicz. 2011. Identification, quantitation and transcriptional profile of potential stem cells in bovine mammary gland. Livest. Sci. 136:136-149.

Murney, R., K. Stelwagen, T. T. Wheeler, J. K. Margerison, and K. Singh. 2015a. The effects of milking frequency in early lactation on milk yield, mammary cell turnover, and secretory activity in grazing dairy cows. J. Dairy Sci. 98:305-311. 
Murney, R., K. Stelwagen, T. T. Wheeler, J. K. Margerison, and K. Singh. 2015b. Activation of signal transducer and activator of transcription 5 (STAT5) is linked to $\beta 1$-integrin protein abundance in unilaterally milked bovine mammary glands. J. Dairy Sci. 98:3133-3142.

Murney, R., K. Stelwagen, T. T. Wheeler, J. K. Margerison, and K. Singh. 2015c. The effects of milking frequency on insulin-like growth factor I signaling within the mammary gland of dairy cows. J. Dairy Sci. 98:5422-5428.

Nair, B. R. K., E. Mathai, and N. Kunjikutty. 1981. A report on lactating male goats. Kerala J. Vet. Sci. 12:145-150.

Nibler, C. W., and C. W. Turner. 1929. The ovarian hormone content of pregnant cow's urine. J. Dairy Sci. 12:491-506.

Nichols, T. 2017. How America lost faith in expertise - and why that's a giant problem. Foreign Aff. 96:60-73.

Nickerson, S. C., C. W. Heald, T. L. Bibb, and M. L. McGilliard. 1978. Cytological effects of hormones and plasma on bovine mammary tissue in vitro. J. Endocrinol. 79:363-368.

Nørgaard, J. V., P. K. Theil, M. T. Sørensen, and K. Sejrsen. 2008. Cellular mechanisms in regulating mammary cell turnover during lactation and dry period in dairy cows. J. Dairy Sci. 91:2319-2327.

Oftedal, O. T. 1993. The adaptation of milk secretion to the constraints of fasting in bears, seals, and baleen whales. J. Dairy Sci. 76:3234-3246.

Ott, I., and J. C. Scott. 1910. The action of infundibulum upon mammary secretion. Proc. Soc. Exp. Biol. 8:48-49.

Park, C. S., J. J. Smith, M. Sasaki, W. N. Eigel, and T. W. Keenan. 1979. Isolation of functionally active acini from bovine mammary gland. J. Dairy Sci. 62:537-545.

Pearson, R. E., L. A. Fulton, P. D. Thompson, and J. W. Smith. 1979 Three times a day milking during the first half of lactation. J. Dairy Sci. 62:1941-1950.

Peel, C. J., and D. E. Bauman. 1987. Somatotropin and lactation. J. Dairy Sci. 70:474-486.

Perruchot, M. H., M. Arevalo-Turrubiate, F. Dufreneix, L. Finot, V. Lollivier, E. Chant, F. Mayeur, and F. Dessauge. 2016. Mammary epithelial hierarchy in the dairy cow throughout lactation. Stem Cells Dev. 25:1407-1418.

Peters, R. R., L. T. Chapin, K. B. Leining, and H. A. Tucker. 1978. Supplemental lighting stimulates growth and lactation in cattle. Science 199:911-912.

Petersen, W. E. 1942. New developments in the physiology and biochemistry of lactation: A review. J. Dairy Sci. 25:71-96.

Piantoni, P., K. M. Daniels, R. E. Everts, S. L. Rodriguez-Zas, H. A. Lewin, W. L. Hurley, R. M. Akers, and J. J. Loor. 2012. Level of nutrient intake affects mammary gland gene expression profiles in preweaned Holstein heifers. J. Dairy Sci. 95:2550-2561.

Pitelka, D. R., and S. T. Hamamoto. 1977. Form and function in mammary epithelium: The interpretation of ultrastructure. J. Dairy Sci. 60:643-654

Plath, A., R. Einspainer, C. Gabler, F. Peters, F. Sinowatz, D. Gospodarowicz, and D. Schams. 1998. Expression and localization of members of the fibroblast growth factor family in the bovine mammary gland. J. Dairy Sci. 81:2604-2613.

Ragsdale, A. C., C. W. Turner, and S. Brody. 1924. The rate of milk secretion as affected by an accumulation of milk in the mammary gland. J. Dairy Sci. 7:249-254.

Rao, D. R., H. M. Hegarty, and B. L. Larson. 1975. Effect of cell density on lactose synthesis in bovine mammary cell cultures. J. Dairy Sci. 58:159-163.

Rauner, G., and I. Barash. 2012. Cell hierarchy and lineage commitment in the bovine mammary gland. PLoS One 7:e30113.

Rauner, G., and I. Barash. 2016. Enrichment for repopulating cells and identification of differentiation markers in the bovine mammary gland. J. Mammary Gland Biol. Neoplasia 21:41-49.

Reece, R. P. 1956. The physiology of milk production. J. Dairy Sci. 39:726-734.

Richmond, P. A., and L. F. Hood. 1973. Tissue culture method for bovine mammary tissue: Lactose synthesis. J. Dairy Sci. 56:611-614.

Rivera, E. M. 1972. Influence of hormones on enzyme activity in mouse mammary gland in vitro. J. Dairy Sci. 55:1308-1316.
Roberts, R. M., G. W. Smith, F. W. Bazer, J. Cibelli, G. E. Seidel Jr., D. E. Bauman, L. P. Reynolds, and J. J. Ireland. 2009. Farm animal research in crisis. Science 324:468-469.

Rowson, A. R., K. M. Daniels, S. E. Ellis, and R. C. Hovey. 2012 Growth and development of mammary glands of livestock: A veritable barnyard of opportunities. Semin. Cell Dev. Biol. 23:557-566.

Safayi, S., N. Korn, A. Bertram, R. M. Akers, A. V. Capuco, S. L. Pratt, and S. Ellis. 2012. Myoepithelial cell differentiation markers in prepubertal bovine mammary gland: Effect of ovariectomy. J. Dairy Sci. 95:2965-2976.

Schams, D., S. Kohlenberg, W. Amselgruber, B. Berisha, M. W. Pfaffl, and F. Sinowaltz. 2003. Expression and localization of oestrogen and progesterone receptors in the bovine mammary gland during development, function and involution. J. Endocrinol. 177:305-317.

Schanbacher, F. L., R. E. Goodman, and R. S. Talhouk. 1993. Bovine mammary lactoferrin: Implications from messenger ribonucleic acid (MRNA) sequence and regulation contrary to other milk proteins. J. Dairy Sci. 76:3812-3831.

Schultze, A. B., and C. W. Turner. 1933. Experimental initiation of milk secretion in the albino rat. J. Dairy Sci. 16:129-139.

Sejrsen, K., J. Foldager, M. T. Sørensen, R. M. Akers, and D. E. Bauman. 1986. Effect of exogenous bovine somatotropin on pubertal mammary development in heifers. J. Dairy Sci. 69:1528-1535.

Sejrsen, K., J. T. Huber, and H. A. Tucker. 1983. Influence of amount fed on hormone concentrations and their relationship to mammary growth in heifers. J. Dairy Sci. 66:845-855.

Sejrsen, K., J. T. Huber, H. A. Tucker, and R. M. Akers. 1982. Influence of nutrition on mammary development in pre- and postpubertal heifers. J. Dairy Sci. 65:793-800.

Sejrsen, K., and S. Purup. 1997. Influence of prepubertal feeding level on milk yield potential of dairy heifers: A review. J. Anim. Sci. 75:828-835.

Senger, P. L. 2008. Will there be another generation of reproductive scientists. Anim. Reprod. Sci. 105:179-186.

Shackelton, M., F. Vaillant, K. J. Simposon, J. Stingl, G. K. Smyth, M. L. Asselin-Labat, L. Wu, G. J. Lindeman, and J. E. Visvader. 2006. Generation of a functional mammary gland from a single stem cell. Nature 439:84-88.

Sheffield, L. G. 1988. Organization and growth of mammary epithelia in the mammary fat pad. J. Dairy Sci. 71:2855-2874.

Silva, L. F. P., J. S. Leisman, B. E. Etchenbarne, M. S. Weber Nielsen, and M. J. VanderHaar. 2005. Short communication: Intramammary infusion of IGF-I increases bromodeoxyuridine labeling in mammary epithelial cells of prepubertal heifers. J. Dairy Sci. 88:2771-2773.

Sinha, Y. N., and H. A. Tucker. 1969. Mammary development and pituitary prolactin level of heifers from birth through puberty and during the estrous cycle. J. Dairy Sci. 52:507-512.

Smith, J. J., A. V. Capuco, and R. M. Akers. 1987. Quantification of progesterone binding in mammary tissue of pregnant ewes. J. Dairy Sci. 70:1178-1185

Smith, K. L., and F. L. Schanbacher. 1973. Hormone-induced lactation in the bovine. I. Lactational performance following injections of 173-estradiol and progesterone. J. Dairy Sci. 56:738-743.

Smith, K. L., and F. L. Schanbacher. 1974. Hormone-induced lactation in the bovine. II. Response of nulligravida heifers to modified estrogen-progesterone treatment. J. Dairy Sci. 57:296-303.

Soberon, F., E. Raffenato, R. W. Everett, and M. E. Van Amburgh. 2012. Preweaning milk replacer intake and effects on long-term productivity of dairy calves. J. Dairy Sci. 95:783-793.

Sørensen, M. T., K. Sejrsen, and J. Foldager. 1987. Estimation of pubertal mammary development in heifers by computed tomography. J. Dairy Sci. 70:265-270.

Stiening, C. M., J. B. Hoying, M. B. Abdallah, A. M. Hoying, R. Pandey, K. Greer, and R. J. Collier. 2008. The effects of endocrine and mechanical stimulation on stage I lactogenesis in bovine mammary epithelial cells. J. Dairy Sci. 91:1053-1066.

Strauss, V. 2017. An 'alternative facts' South Dakota bill sparks fears for science education in the Trump era. Washington Post, February 5, 2017. https://www.washingtonpost.com/news/answer -sheet/wp/2017/02/05/an-alternative-facts-south-dakota-bill 
-sparks-fears-for-science-education-in-the-trump-era/?utm_term= cefc22da22aa.

Sud, S. C., H. A. Tucker, and J. Meites. 1968. Estrogen-progesterone requirements for udder development in ovariectomized heifers. J. Dairy Sci. 51:210-214.

Swett, W. W. 1927. Relationship of conformation and anatomy of the dairy cow to her milk and butterfat producing capacity. J. Dairy Sci. 10:1-14.

Swett, W. W. 1947. A cow a calf will be. USDA Yearbook of Agriculture 1943-1947. USDA, Washington, DC.

Swett, W. W., and C. A. Matthews. 1934. Dairy cow's udder studies to establish development standards. USDA Yearbook of Agriculture 175-181. USDA, Washington, DC.

Sykes, J. F., and T. R. Wrenn. 1950. Hormonal development of the mammary gland of dairy heifers. J. Dairy Sci. 33:194-204.

Sykes, J. F., and T. R. Wrenn. 1951. Hormonal development of mammary tissue in dairy heifers. J. Dairy Sci. 34:1174-1179.

Thompson, M. P. 1973. A perspective for dairy research-Abridged comments. J. Dairy Sci. 56:1185-1186.

Tucker, H. A. 1981. Physiological control of mammary growth, lactogenesis, and lactation. J. Dairy Sci. 64:1403-1421.

Tucker, H. A. 1987. Quantitative estimates of mammary growth during various physiological states: A review. J. Dairy Sci. 70:1958-1966.

Tucker, H. A. 2000. Hormones, mammary growth, and lactation: A 41-year perspective. J. Dairy Sci. 83:874-884.

Tucker, H. A., R. P. Reece, and R. E. Mather. 1961. Udder capacity estimates as affected by rate of milk secretion and intramammary pressure. J. Dairy Sci. 44:1725-1732.

Tucker, H. L. M., C. L. M. Parsons, S. Ellis, M. L. Rhoads, and R. M. Akers. 2016. Tamoxifen impairs prepubertal mammary development and alters expression of estrogen receptor $\alpha$ (ESR1) and progesterone receptors (PGR). Domest. Anim. Endocrinol. 54:95-105.

Turner, C. W. 1952. The Mammary Gland. Lucas Brothers, Columbia, MO.

Turner, C. W., H. Yamamoto, and H. L. Ruppert Jr. 1956. The experimental induction of growth of the cow's udder and the initiation of milk secretion. J. Dairy Sci. 39:1717-1729.

Velayudhan, B. T., B. P. Huderson, S. E. Ellis, C. L. Parsons, R. C. Hovey, A. R. Rowson, and R. M. Akers. 2015. Ovariectomy in young prepubertal dairy heifers causes complete suppression of mammary progesterone receptors. Domest. Anim. Endocrinol. 51:8-18.
Wall, E. H., H. M. Crawford, S. E. Ellis, G. E. Dahl, and T. B. McFadden. 2006. Mammary response to exogenous prolactin or frequent milking during early lactation in dairy cows. J. Dairy Sci. 89:4640-4648.

Wall, E. H., and T. B. McFadden. 2010. The effects of milk removal or four-times-daily milking on mammary expression of genes involved in the insulin-like growth factor-I axis. J. Dairy Sci. 93:4062-4070.

Wang, M., Z. Zhou, M. J. Khan, J. Gao, and J. J. Loor. 2015. Clock circadian regulator (CLOCK) gene network expression patterns in bovine adipose, liver, and mammary gland at 3 time points during the transition from pregnancy into lactation. J. Dairy Sci. 98:4601-4612.

Watters, R. D., R. M. Bruckmaier, H. M. Crawford, N. Schruing Y. H. Schukken, and D. M. Galton. 2015. The effect of manual and mechanical stimulation on oxytocin release and milking characteristics in Holstein cows milked 3 times daily. J. Dairy Sci. 98:1721-1729

Weaver, S. R., and L. L. Hernandez. 2016. Autocrine-paracrine regulation of the mammary gland. J. Dairy Sci. 99:842-853.

Weber, M. S., S. Purup, M. Vestergaard, R. M. Akers, and K. Sejrsen. 2000. Regulation of local synthesis of insulin-like growth factor-I and binding proteins in mammary tissue. J. Dairy Sci. 83:30-37.

Weiss, D., M. Weinfurtner, and R. M. Bruckmaier. 2004. Teat anatomy and its relationship with quarter and udder milk follow characteristics in dairy cows. J. Dairy Sci. 87:3280-3289.

Weiss, G. R. 2017. When the stakes are high, science remains our best bet. Letter to Editor, Washington Post, February 2, 2017. https://www.washingtonpost.com/opinions/when-the-stakes-are -high-science-remains-our-best-bet/2017/02/02/531ecce4-e802 -11e6-903d-9b11ed7d8d2a_story.html?utm_term=.97b19ddb9399.

Williams, R., and C. W. Turner. 1961a. Effect of increased levels of ovarian hormones and duration of treatment on the experimental induction of growth of the cow's udder. J. Dairy Sci. 44:524-534.

Williams, R., and C. W. Turner. 1961b. Growth of the calf udder using DNA as an index. J. Dairy Sci. 44:1721-1724.

Wilson, M. L., S. R. McCoski, A. J. Geiger, R. M. Akers, S. E. Johnson, and R. M. Akers. 2017. The influence of postnatal nutrition on reproductive tract and endometrial gland development in dairy calves. J. Dairy Sci. 100:3243-3256.

Zanton, G. I., and A. J. Heinrichs. 2005. Meta-analysis to assess effect of prepubertal average daily gain of Holstein heifers on firstlactation production. J. Dairy Sci. 88:3860-3867. 


\section{APPENDIX}

Table A1. Timeline of important discoveries and developments in mammary development and lactation

\begin{tabular}{|c|c|c|}
\hline Date & Milestone & Reference \\
\hline 1910s-1920s & $\begin{array}{l}\text { Mammary active hormones are discovered, including oxytocin, } \\
\text { ovarian hormones, and anterior pituitary hormones. }\end{array}$ & $\begin{array}{l}\text { Ott and Scott, 1910; Allen and } \\
\text { Doisy, 1923; Stricker and Grueter, } \\
1928 \text { (reviewed in Tucker, 2000) }\end{array}$ \\
\hline $1930 s$ & Evaluations of mammary growth and development are published. & $\begin{array}{l}\text { Swett and Matthews, 1934; Turner, } \\
1952 \text { (review and summary) }\end{array}$ \\
\hline 1936 & $\begin{array}{l}\text { First large-scale report is published on the galactopoietic effect of } \\
\text { growth hormone (pituitary extracts) in cows. }\end{array}$ & Asimov and Krouze, 1936 \\
\hline $1940 s$ & $\begin{array}{l}\text { Study effects of milk frequency, milk removal, breeds, nutrition, } \\
\text { thyroproteins, exogenous hormones, and milk ejection reflex are } \\
\text { reported. }\end{array}$ & $\begin{array}{l}\text { Lewis and Turner, 1941; Peterson, } \\
1942\end{array}$ \\
\hline 1953 & DNA is first used to quantify mammary growth (in rat). & Kirkham and Turner, 1953 \\
\hline $1960 s$ & Cell and tissue culture techniques are developed for bovine. & Ebner et al., 1961 \\
\hline 1961 & DNA is first used to quantify mammary growth in bovine. & Williams and Turner, 1961a,b \\
\hline 1964 & $\begin{array}{l}\text { Restoration of milk production is demonstrated in } \\
\text { hypophysectomized goat. }\end{array}$ & Cowie et al., 1964 \\
\hline 1969 & $\begin{array}{l}\text { Isometric versus allometric mammary growth (DNA) is described in } \\
\text { peripubertal heifers. }\end{array}$ & Sinha and Tucker, 1969 \\
\hline 1960s-1970s & $\begin{array}{l}\text { Radioisotopes are used to measure milk component biosynthesis } \\
\text { and mammary tissue enzyme activity. }\end{array}$ & $\begin{array}{l}\text { Baldwin, 1966; Larson, 1972; } \\
\text { Mellenberger et al., } 1973\end{array}$ \\
\hline 1970 s & $\begin{array}{l}\text { Radioimmunoassays are developed for hormones and growth factors } \\
\text { in bovine blood and milk. }\end{array}$ & $\begin{array}{l}\text { Hansel and Snook, 1970; } \\
\text { Koprowski and Tucker, } 1971 ; \\
\text { Malven and McMurtry, } 1974\end{array}$ \\
\hline 1973 & Shortened induced lactation scheme is reported for bovine. & $\begin{array}{l}\text { Smith and Schanbacher, 1973, } \\
1974\end{array}$ \\
\hline 1976 & Glucocorticoid receptors are measured in bovine mammary tissue. & Gorewit and Tucker, 1976a,b \\
\hline 1977 & $\begin{array}{l}\text { Lactogenic complex is demonstrated in explant cultures of bovine } \\
\text { mammary tissue. }\end{array}$ & $\begin{array}{l}\text { Collier et al., 1977; Nickerson et al., } \\
1978\end{array}$ \\
\hline 1978 & $\begin{array}{l}\text { Effects of an increased photoperiod on milk production are described } \\
\text { in cows. }\end{array}$ & $\begin{array}{l}\text { Peters et al., } 1978 \text { (reviewed by } \\
\text { Dahl et al., 2000) }\end{array}$ \\
\hline $1980 \mathrm{~s}$ & Steroid and prolactin receptors are measured in bovine tissue. & $\begin{array}{l}\text { Capuco et al., 1982; Akers and } \\
\text { Keys, } 1984\end{array}$ \\
\hline
\end{tabular}


Table A1 (Continued). Timeline of important discoveries and developments in mammary development and lactation

\begin{tabular}{|c|c|c|}
\hline Date & Milestone & Reference \\
\hline 1982 & $\begin{array}{l}\text { Nutrition is shown to affect periparturient mammary development in } \\
\text { bovine. }\end{array}$ & Sejrsen et al., 1982, 1983 \\
\hline 1984 & Lactogenic hormone receptors described in bovine mammary tissue. & Akers and Keys, 1984 \\
\hline 1985 & $\begin{array}{l}\text { Galactopoietic effectiveness and safety of recombinant bST is } \\
\text { demonstrated. }\end{array}$ & Bauman et al., 1985 \\
\hline 1986 & $\begin{array}{l}\text { Growth hormone regulation of mammary growth is demonstrated in } \\
\text { peripubertal heifers. }\end{array}$ & \\
\hline 1988 & $\begin{array}{l}\text { Early gene expression studies in bovine are conducted using } \\
\text { Northern analysis and other techniques. }\end{array}$ & Choi et al., 1988 \\
\hline $1990 \mathrm{~s}$ & $\begin{array}{l}\text { Initial measures of gene expression in bovine mammary gland are } \\
\text { reported. }\end{array}$ & $\begin{array}{l}\text { Schanbacher et al., 1993; Koff and } \\
\text { Plaut, } 1995\end{array}$ \\
\hline 1992 & $\begin{array}{l}\text { Bovine somatotropin is recognized as an emerging animal } \\
\text { technology. }\end{array}$ & Bauman, 1992 \\
\hline 1994 & $\begin{array}{l}\text { US Food and Drug Administration approves recombinant bST for use } \\
\text { in lactating cows. }\end{array}$ & Bauman et al., 1999 \\
\hline 1990s-2000s & $\begin{array}{l}\text { Transgenic animals and the mammary gland as bioreactor show } \\
\text { fleeting promise. }\end{array}$ & $\begin{array}{l}\text { Karatzas and Turner, 1997; Bremel } \\
\text { et al., 2001; Donovan et al., } 2001\end{array}$ \\
\hline $1990 s-2000 s$ & $\begin{array}{l}\text { Researchers recognize effects of altered photoperiods, milking } \\
\text { frequency, and environment (e.g., heat stress) on mammary } \\
\text { development and function. }\end{array}$ & Dahl et al., 2000; Collier et al., 2006 \\
\hline 2003 & $\begin{array}{l}\text { Estrogen and progesterone receptors are localized in bovine } \\
\text { mammary gland using immunocytochemistry. }\end{array}$ & Schams et al., 2003 \\
\hline 2003-2010 & $\begin{array}{l}\text { Milking frequency in early lactation is shown to have carry-over } \\
\text { effects on mammary gene expression. }\end{array}$ & $\begin{array}{l}\text { Hale et al., 2003; Wall et al., 2006, } \\
\text { Wall and McFadden, } 2010\end{array}$ \\
\hline 2007 & $\begin{array}{l}\text { Ovarian steroids are shown to regulate gene expression in bovine } \\
\text { mammary gland. }\end{array}$ & Connor et al., 2007 \\
\hline 2008 & $\begin{array}{l}\text { Evolving significance of serotonin and its receptors in local regulation } \\
\text { of mammary function is recognized. }\end{array}$ & $\begin{array}{l}\text { Hernandez et al., } 2008 \text { (reviewed } \\
\text { in Weaver and Hernandez, 2016) }\end{array}$ \\
\hline 2008 & $\begin{array}{l}\text { The lactocrine hypothesis-mammary secretions are more than just } \\
\text { neonatal nutrition-is proposed. }\end{array}$ & Bartol et al., 2008 \\
\hline 2010-current & $\begin{array}{l}\text { Bovine mammary "-omics" data (e.g., proteomics, transcriptomics, } \\
\text { metabolomics) continue to rapidly expand. }\end{array}$ & Wang et al., 2015 \\
\hline 2010-current & Putative bovine mammary stem cells are discovered and identified. & $\begin{array}{l}\text { Capuco and Ellis, 2013; Rauner } \\
\text { and Barash, } 2016\end{array}$ \\
\hline
\end{tabular}

